\title{
Modelled thermal and dynamical responses of the middle atmosphere to EPP-induced ozone changes
}

K. Karami ${ }^{1}$, P. Braesicke ${ }^{1}$, M. Kunze ${ }^{2}$, U. Langematz ${ }^{2}$, M. Sinnhuber ${ }^{1}$, and S. Versick ${ }^{1,3}$

${ }^{1}$ Institute for Meteorology and Climate Research, Karlsruhe Institute of Technology, Karlsruhe, Germany

${ }^{2}$ Institute for Meteorology, Freie Universität Berlin, Berlin, Germany

${ }^{3}$ Steinbuch Centre for Computing, Karlsruhe Institute of Technology, Karlsruhe, Germany

Received: 12 October 2015 - Accepted: 9 November 2015 - Published: 25 November 2015

Correspondence to: K. Karami (khalil.karami@kit.edu)

Published by Copernicus Publications on behalf of the European Geosciences Union.

Dynamical impact of energetic particles

K. Karami et al.

\section{Title Page}

Abstract

Conclusions

Tables

14

4

Back

Full Screen / Esc

Printer-friendly Version

Interactive Discussion 


\section{Abstract}

Energetic particles including protons, electrons and heavier ions, enter the Earth's atmosphere over the polar regions of both hemispheres, where they can greatly disturb the chemical composition of the upper and middle atmosphere and contribute to ozone 5 depletion in the stratosphere and mesosphere. The chemistry-climate general circulation model EMAC is used to investigate the impact of changed ozone concentration due to Energetic Particle Precipitation (EPP) on temperature and wind fields. The results of our simulations show that ozone perturbation is a starting point for a chain of processes resulting in temperature and circulation changes over a wide range of latitudes altitudes. In both hemispheres, as winter progresses the temperature and wind anomalies move downward with time from the mesosphere/upper stratosphere to the lower stratosphere. In the Northern Hemisphere $(\mathrm{NH})$, once anomalies of temperature and zonal wind reach the lower stratosphere, another signal develops in mesospheric heights and moves downward. Analyses of Eliassen and Palm (EP) flux divergence

with positive and negative anomalies of the EP flux divergences, respectively. This results suggest that the oscillatory mode in the downwelling signal of temperature and zonal wind in our simulations are the consequence of interaction between the resolved waves in the model and the mean stratospheric flow. Therefore, any changes in the EP flux divergence lead to anomalies in the zonal mean zonal wind which in turn feed back on the propagation of Rossby waves from the troposphere to higher altitudes. The analyses of Rossby waves refractive index show that the EPP-induced ozone anomalies are capable of altering the propagation condition of the planetary-scale Rossby waves in both hemispheres. It is also found that while ozone depletion was confined 25 to mesospheric and stratospheric heights, but it is capable to alter Rossby wave propagation down to tropospheric heights. In response to an accelerated polar vortex in the Southern Hemisphere (SH) late wintertime, we found almost two weeks delay in the occurrence of mean dates of Stratospheric Final Warming (SFW). These results
ACPD

15, 33283-33329, 2015

Dynamical impact of energetic particles

K. Karami et al.

Title Page

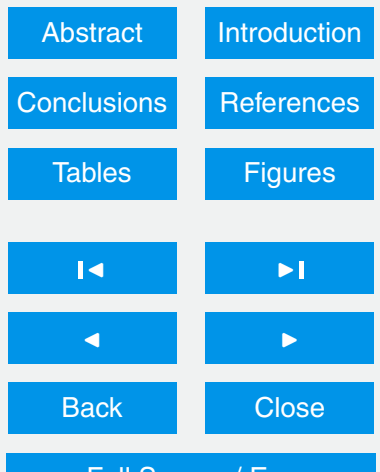

Full Screen / Esc

Printer-friendly Version

Interactive Discussion 
suggest that the stratosphere is not merely a passive sink of wave activity from below, but it plays an active role in determining its own budget of wave activity.

\section{Introduction}

Charged particles including protons, electrons and heavier ions can impact the mid5 dle atmosphere (mesosphere and stratosphere) through ionization, dissociation and excitation of atmospheric constituents. Such Energetic Particle Precipitation (EPP) can alter the chemical composition of the upper and middle atmosphere. EPP can affect different altitude and geographic regions, mainly due to their different sources and hence have different energy spectra and interact differently with the terrestrial magnetic field 10 (M. Sinnhuber et al., 2012; Jackman et al., 2007). At polar latitudes, EPP has the potential to penetrate deep into the mesosphere and on rare occasions into the stratosphere. Most important are changes to the budget of atmospheric nitric oxides, $\mathrm{NO}_{y}(\mathrm{~N}, \mathrm{NO}$, $\mathrm{NO}_{2}, \mathrm{NO}_{3}, \mathrm{~N}_{2} \mathrm{O}_{5}, \mathrm{HNO}_{3}, \mathrm{HO}_{2} \mathrm{NO}_{2}, \mathrm{HONO}, \mathrm{CLONO}_{2}, \mathrm{CLNO}_{2}, \mathrm{BrONO}_{2}$ ) and to atmospheric reactive hydrogen oxides, $\mathrm{HO}_{x}\left(\mathrm{H}, \mathrm{OH}, \mathrm{HO}_{2}\right)$, which both contribute to ozone 15 loss in the stratosphere and mesosphere. $\mathrm{HO}_{X}$ is a short-lived species, however odd nitrogen $\left(\mathrm{NO}_{y}\right)$ (produced by energetic particles and in the absence of solar radiation) has a lifetime of days to weeks in the mesosphere and months or longer in the stratosphere. So, if dynamical conditions permit, the $\mathrm{NO}_{y}$ produced by energetic particles can be transported downward via the prevailing air motions, consistent with the meridional circulation, into the stratosphere during polar winter. Both $\mathrm{HO}_{x}$ and $\mathrm{NO}_{y}$ can then catalytically destroy ozone in the mesosphere and stratosphere (Funke et al., 2014; Randall et al., 2009).

Although the UV radiation is only a small proportion of the total incoming solar irradiance, it has a relatively large 11 year Solar Cycle (SC) variation. The UV part of the solar spectrum is crucially important for ozone production and middle atmosphere heating. UV variations of up to $6 \%$ are present near $200 \mathrm{~nm}$ where oxygen dissociation and ozone production occur and up to $4 \%$ in the region of $240-320 \mathrm{~nm}$ where

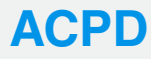

15, 33283-33329, 2015

Dynamical impact of energetic particles

K. Karami et al.

Title Page

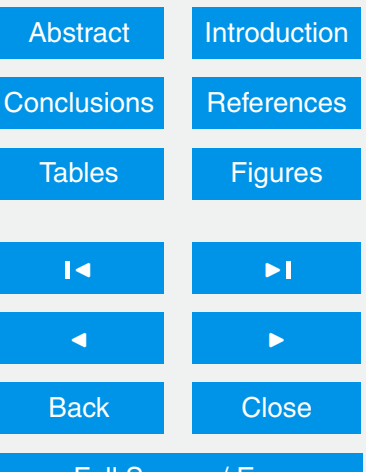

Full Screen / Esc

Printer-friendly Version

Interactive Discussion 
absorption by stratospheric ozone is prevalent. Smaller variations from $0.5 \%$ around $300 \mathrm{~nm}$, and $0.1 \%$ above $400 \mathrm{~nm}$ are also reported (Lean et al., 1997; Woods and Rottman, 2002). Larger UV variability is also observed at shorter wavelengths (over $50 \%$ at $120 \mathrm{~nm}$ ) that are mainly absorbed in the mesosphere and thermosphere. An5 nual averaged estimates of solar maximum minus solar minimum ozone differences from a multiple regression analysis of satellite observations show that in response to UV variation a statistically significant ozone variation of up to $4 \%$ is evident over the tropical stratopause (Soukharev and Hood, 2006). Therefore any modification of ozone in this region can potentially have significant impact on local temperatures and alter 10 the propagation properties for planetary and smaller-scale waves that drive the global circulation. Thus relatively weak, direct radiative forcing over the tropical stratopause could lead to a large indirect dynamical response in the atmosphere.

The impact of ozone depletion on the middle atmosphere circulation and temperature has been the subject of intensive research in the past (Christiansen et al., 1997; Kiehl 5 and Boville, 1988; Braesicke and Pyle, 2003; Langematz et al., 2003; B. M. Sinnhuber et al., 2012). Moreover, chemical changes of the middle atmosphere due to EPP has been the subject of different studies (Jackman et al., 2000; Seppälä et al., 2004; Rozanov et al., 2005; Marsh et al., 2007; Päivärinta et al., 2013; Randall et al., 1998; Langematz et al., 2005; Funke et al., 2005; Andersson et al., 2014). For instance,

Rozanov et al. (2005) studied the impact of additional $\mathrm{NO}_{y}$ sources caused by energetic electron precipitation in a Chemistry-Climate Model (CCM). Comparison of two model runs with and without EPP revealed an increase of reactive nitrogen and a subsequent enhancement of ozone depletion.

Baumgaertner et al. (2011) investigated the response of tropospheric temperature variability in polar regions due to mesospheric $\mathrm{NO}_{x}$ enhancement, which was reported earlier by Seppälä et al. (2009). Their model results showed a significant perturbation of the middle and lower atmosphere during polar winter. The $\mathrm{NO}_{x}$ production due to geomagnetic activity lead to ozone depletion in the stratosphere, changing the radiative budget, modifying the temperature distribution and circulation. A warming in the $\mathrm{NH}$

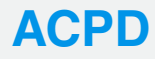

15, 33283-33329, 2015

Dynamical impact of energetic particles

K. Karami et al.

Title Page

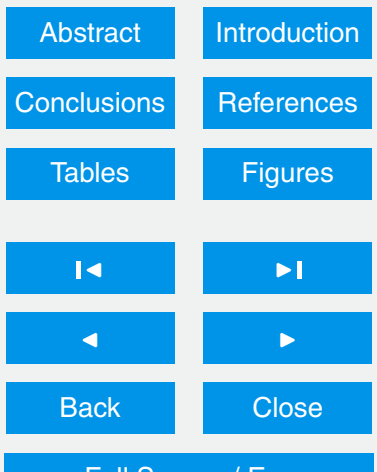

Full Screen / Esc

Printer-friendly Version

Interactive Discussion 
polar winter upper stratosphere and mesosphere was modelled, while lower altitudes (5 to $110 \mathrm{hPa}$ ) showed cooling with a strenthened polar vortex. However, the underlying mechanism of the simulated downward descent of the stratospheric signal to the surface remained unclear. In addition, studies of Baumgaertner et al. (2011); Lu et al. 5 (2008); Randall et al. (2005); Seppälä et al. (2013) demonstrated the importance of dynamical conditions on the interaction of energetic particles and climate.

By implementing idealised ozone anomalies at different altitudes throughout the year, following the analyses of Fytterer et al. (2014), we provide a sensitivity study addressing the thermal and dynamical effects of EPP induced composition change in the mid10 dle atmosphere. We investigate direct thermal (short and long wave heating rates) and indirect (thermo-)dynamical (e.g. temperature and zonal wind) responses of the EMAC model to the prescribed ozone anomalies. The divergence and convergence of heat and momentum fluxes are calculated to determine the impact of dissipating planetary waves on the zonal mean flow. In addition, we study the changes in stratospheric wave 15 propagation characteristics associated with EPP-induced ozone anomalies in unprecedented detail. Finally, we investigated the possible effect of EPP-induced ozone loss on frequency and timing of stratospheric warmings.

\section{Chemistry climate model and scenarios}

\subsection{Model system EMAC}

20 We use the ECHAM/MESSy Atmospheric Chemistry (EMAC) general circulation model version 2.42.2 to perform the simulations. EMAC is a numerical chemistry and climate simulation system that includes submodels describing tropospheric and middle atmosphere processes and their interactions with oceans, land, and human influences (Jöckel et al., 2006). It uses the second version of the Modular Earth submodel System (MESSy2) to link multi-institutional computer codes. The core atmospheric model is the 5th generation European Centre Hamburg general circulation model ECHAM5 (Roeck-

\section{ACPD}

15, 33283-33329, 2015

Dynamical impact of energetic particles

K. Karami et al.

Title Page

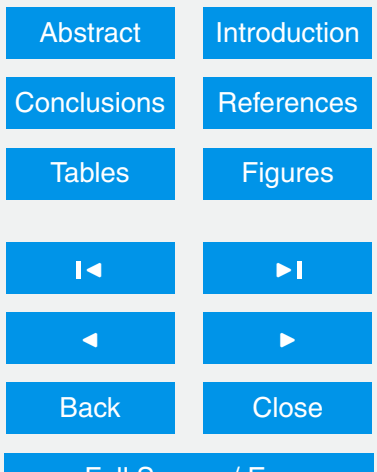

Full Screen / Esc

Printer-friendly Version

Interactive Discussion 
ner et al., 2004). ECHAM solves the atmospheric primitive equations horizontally via a spectral transform technique. In the vertical it uses the method of finite differences and for time integration a semi-implicit leap-frog scheme with time filter.

For the present study we applied EMAC (ECHAM5 version 5.3.02) in the T42L90MA5 resolution, i.e. with a spherical truncation of T42 (corresponding to a quadratic Gaussian grid of approximately $2.8^{\circ}$ by $2.8^{\circ}$ in latitude and longitude) with 90 hybrid pressure levels up to $0.01 \mathrm{hPa}$. The applied model set up comprised the submodels RAD4ALL, CONVECT, GWAVE and CLOUD. Interactive chemistry is not used in this study. Instead constant mixing ratios are assumed for $\mathrm{CO}_{2}, \mathrm{CH}_{4}, \mathrm{~N}_{2} \mathrm{O}, \mathrm{CFC}-11$ and CFC-12, 10 whereas a climatology (FUB-ozone) is used for $\mathrm{O}_{3}$.

Moreover, in order to examine the internal dynamical response of the model atmosphere to a changed ozone, several time-slice model runs are carried out over a period of 100 years (1982 year condition) with a free-running version of the model with constant boundary conditions (average incoming solar flux, sea ice distribution and SST) 15 during the whole year. However, these boundary conditions have a seasonal cycle. Details of four simulations performed for the current study are presented in Table 1.

\subsection{Radiation in EMAC}

The submodel RAD4ALL (Jöckel et al., 2006) is a reimplementation into the MESSy standard of the ECHAM5 radiation code which is based on Fouquart and Bonnel (1980) (FB1980) for the solar part of the spectrum (250-4000 nm), and on the Rapid Radiative Transfer Model (RRTM) (Mlawer et al., 1997) in the terrestrial (long wave) part of the spectrum (3 March $1000 \mu \mathrm{m}$ ). The terrestrial part of the spectrum is subdivided into 16 spectral bands, and includes line absorption by $\mathrm{H}_{2} \mathrm{O}, \mathrm{CO}_{2}, \mathrm{O}_{3}, \mathrm{CH}_{4}, \mathrm{~N}_{2} \mathrm{O}, \mathrm{CFCs}$, and aerosols.

25 The solar part is subdivided into four bands (Roeckner et al., 2004), one covering the ultraviolet and visible (UV-Vis) and three bands covering the near infrared (NIR) part of the solar spectrum. FB1980 uses the Eddington approximation for the integration over the zenith and azimuth angles and the delta-Eddington approximation for the 33288
ACPD

15, 33283-33329, 2015

Dynamical impact of energetic particles

K. Karami et al.

Title Page

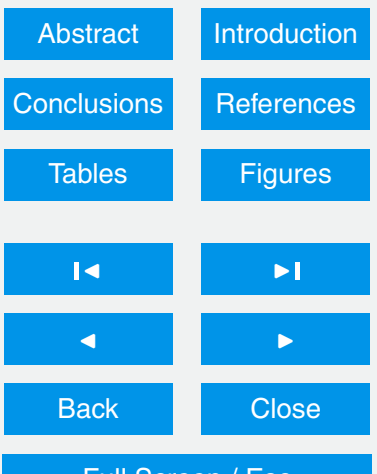

Full Screen / Esc

Printer-friendly Version

Interactive Discussion 
reflectivity of a layer. The scheme includes Rayleigh scattering on aerosols and cloud particles, absorption by water vapor and ozone, both varying in space and time, and other radiatively active trace gases as uniformly mixed gases.

To achieve a better representation of the solar cycle (which needs higher spectral 5 resolution) in EMAC, Nissen et al. (2007) developed the sub-submodel RAD4ALLFUBRAD. FUBRAD is a high resolution short wave radiation scheme with 49 bands ranging from 121.5-683 nm (Table 2), which substitutes the UV-Vis band of FB1980 in the stratosphere and mesosphere between 70 (well above the cloud level) and $0.01 \mathrm{hPa}$. It takes into account the relevant radiative processes in this altitude range 10 (approximately 18 and $80 \mathrm{~km}$ ), i.e. heating due to absorption of UV-Vis radiation by molecular oxygen and by ozone. The full radiation is called every third time step, whereas FUBRAD calculates heating rates every time step.

\subsection{Ozone perturbation scenarios}

In this study the monthly mean ozone climatology of Fortuin and Langematz (1994) is used (FUB-ozone). It has 34 vertical levels ranging from 1000 to $0.003 \mathrm{hPa}$. Figure 1 shows the annual mean of the FUB-ozone climatology in volume mixing ratio (ppmv). Based on the study of Fytterer et al. (2014), several model runs are performed that are identical except for the prescribed ozone climatology. Figure 2 (left) summarises the changes applied to the base climatology as a function of altitude and time. We use a scenario for the $\mathrm{NH}$ in which the ozone mixing ratio is decreased by $30 \%$ in early winter in the mesosphere and this signal moves downward until it reaches the lower stratosphere in late winter and early spring. These idealised EPP-induced ozone anomalies are applied to the ozone volume mixing ratios of FUB-ozone in both the northern $\left(60-90^{\circ} \mathrm{N}\right)$ and the southern $\left(60-90^{\circ} \mathrm{S}\right)$ hemisphere. Hereafter ozone change

Two additional model runs were carried out with a prescribed ozone change of $-4 \%$ (Soukharev and Hood, 2006) around the tropical stratopause (Fig. 2 right) for each of the polar changes in the $\mathrm{NH}$ or $\mathrm{SH}$. Hereafter this scenario will be called $\left(\Delta \mathrm{O}_{3}-\mathrm{TS}\right)$.

\section{ACPD}

15, 33283-33329, 2015

Dynamical impact of energetic particles

K. Karami et al.

Title Page
Abstract

Conclusions

Tables

14

4

Back
Introduction

References

Figures

$>1$

>

Close
Full Screen / Esc

Printer-friendly Version

Interactive Discussion 


\section{Direct radiative impact of ozone depletion}

Short wave absorption by ozone is weakly temperature dependent. However, long term changes in long wave radiation due to imposed ozone depletion is highly temperature dependent. Following Langematz et al. (2003), we isolate the processes responsible 5 for the thermal and dynamical changes in the model simulations. In order to separate the direct radiative forcing of the ozone changes in EMAC, we compared the initial heating rates stored at the first output time step of the experiments after a day of integration. Since the radiative relaxation time is about 3-7 days in the upper stratosphere and about 20 days in the lower stratosphere, a time interval of a day is too short for the atmosphere to adjust thermally to the radiative forcing. In addition, within one day the impact of dynamical heating rate changes on the long wave cooling rate is largely negligible (Brasseur, 2005). Considering the characteristic time period of planetary wave oscillations at mesospheric and lower thermospheric altitudes (Karami et al., 2012) for higher long wave integrations over time especially more than 2 days, relaxation times

15 are comparable to planetary wave periods, implying strong damping (depositing energy and momentum) of planetary waves there. Thus we interpret changes in the long wave cooling rate as a direct radiative forcing due to the imposed ozone depletion. The initial change to the short wave heating rate due to imposed ozone depletion is shown in Fig. 3 (left). As expected, in the polar night region the prescribed ozone anomalies in early and mid-winter affect the sun-lit region only. The differences in short wave heating rates in both hemispheres have very similar characteristics. Small differences are caused by different climatological ozone (we apply relative changes). In relative terms the strongest short wave heating rate changes occur in the upper stratosphere and stratopause region. However, short wave heating rate differences vanish at the terminator. In early $\mathrm{NH}$ spring (April) ozone depletion has an impact in all latitude ranges in the lower stratosphere, since all latitudes around this height are sunlit. In the lower stratosphere of the $\mathrm{SH}$, the imposed ozone deficit leads to reduced short wave heating of $0.2 \mathrm{Kday}^{-1}$. In the upper stratosphere and mesosphere, enhanced absorption of
ACPD

15, 33283-33329, 2015

Dynamical impact of energetic particles

K. Karami et al.

Title Page

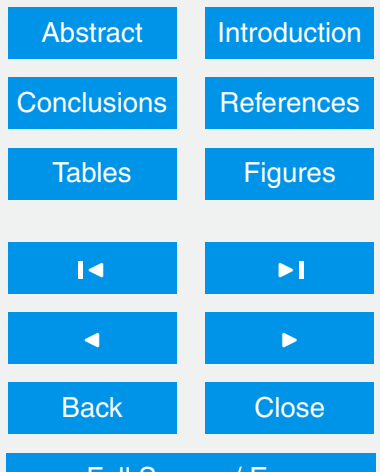

Full Screen / Esc

Printer-friendly Version

Interactive Discussion 
solar radiation, which has not been absorbed above due to ozone loss, result in local heating. This feature is most pronounced in December of the $\mathrm{NH}$ and June of the $\mathrm{SH}$.

The initial change to the long wave heating rate due to the imposed ozone depletion is shown in Fig. 3 (right). There are only small differences between the response 5 in both hemispheres, since the distribution of radiative heating rates is strongly coupled to both the distribution of ozone and outgoing long wave radiation. Contrary to the cooling effect of the imposed ozone depletion due to less short wave absorption, the long wave heating rate changes show an opposite behavior above and below the stratopause region. In the upper stratosphere and mesosphere, less ozone leads to

10 a relative warming. Since in these altitudes ozone locally emits long wave radiation and cools the atmosphere, less cooling due to less ozone results in a relative warming. In contrast, the lower stratosphere cools weakly due to ozone loss up to $0.1 \mathrm{Kday}^{-1}$, because less ozone absorbs less outgoing long wave radiation and leads to a relative cooling. Thus the net radiative heating rate at high latitudes is dominated by a warming due to the long wave component in the upper stratosphere and mesosphere, where the effect of short wave heating in the dark wintertime polar region is negligible. But in the middle and lower stratosphere, both short wave and long wave heating rates contribute to a local cooling effect.

\section{Temperature and zonal wind response to imposed ozone anomalies}

20 In this section, composite analyses are performed to show the impact of the imposed ozone changes on temperature and zonal wind. All our analyses are performed using multi-year monthly means of zonally averaged values for both zonal wind and temperature, covering tropical to polar regions of both hemispheres in the meridional-vertical cross section. In order to be able to show the significance of the temperature and

mean zonal wind response to the imposed ozone change, the differences between the control simulation and the ozone-perturbed simulations are compared with the inter-annual variability of the control simulation. Figure 4 shows a meridional cross
ACPD

15, 33283-33329, 2015

Dynamical impact of energetic particles

K. Karami et al.

Title Page

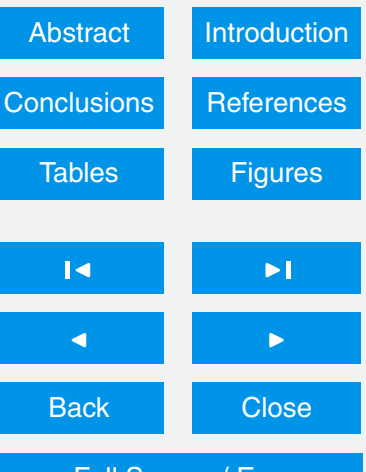

Full Screen / Esc

Printer-friendly Version

Interactive Discussion 
section of the monthly mean temperature changes between $\left(\Delta \mathrm{O}_{3}-\mathrm{NH}\right)$ scenario and control run for November, December, January and February. Contour values represent the differences in monthly and zonal mean temperatures and shaded areas denote the significance levels. The contour interval is $\pm 1 \mathrm{~K}$.

5 A statistically significant positive temperature change is found at mesospheric altitudes of the $\mathrm{NH}$ polar region in November. The magnitude of this positive signal is about $4 \mathrm{~K}$. At the same time, there is a statistically significant negative temperature signal in the stratosphere. This negative anomaly moves downward in December, reaching tropospheric altitudes, while the mesospheric positive temperature signal 10 moves downward and a negative signal of temperature appears above. As winter progresses a downward movement of both positive and negative temperature anomalies from mesospheric and upper stratospheric altitudes to the lower stratospheric altitudes is evident. However, the temperature responses are not statistically significant in the middle and late winter of the $\mathrm{NH}$. Moreover, a tropospheric signal of temperature of 15 about $-1 \mathrm{~K}$ is evident only in December.

Figure 5 shows a meridional cross section of the monthly mean temperature changes between $\left(\Delta \mathrm{O}_{3}-\mathrm{SH}\right)$ scenario and the control run for May, July, August and October. With reduced ozone, the $\mathrm{SH}$ polar mesosphere cools about $1 \mathrm{~K}$, where the negative signal exceeds the $\pm 3 \sigma$ inter-annual variability of the control simulation. However, the upper and middle stratosphere show a statistically significant warming effect. While these negative anomalies vanish in June (not shown), as winter progresses from July to October the negative signal moves downward with time. However, neither the robustness nor the strength of this anomaly are constant over time. A negative signal of up to $-4 \mathrm{~K}$ is evident in the middle stratosphere in August. The magnitude of the negative temperof the temperature signal due to additional sources of energetic particles from mesospheric and upper stratospheric altitudes to the tropospheric altitudes has been previously reported by Rozanov et al. (2005); Baumgaertner et al. (2011); Seppälä et al. (2013). Baldwin and Dunkerton (2001) reported that large variations in the strength

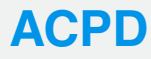

15, 33283-33329, 2015
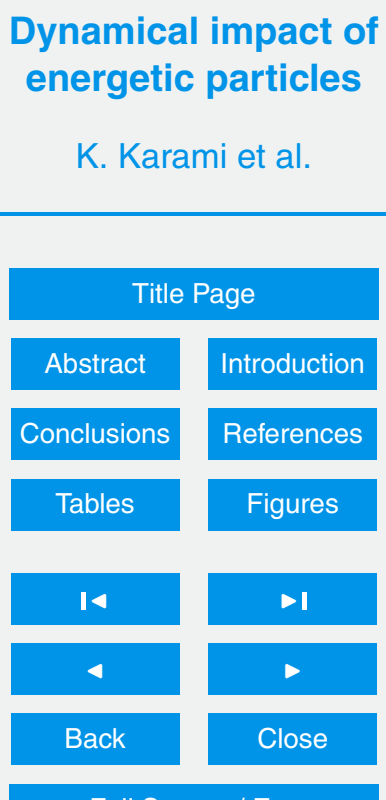

Full Screen / Esc

Printer-friendly Version

Interactive Discussion 
of the stratospheric circulation, appearing first above the stratopause, descend to the lowermost stratosphere and are followed by anomalous tropospheric weather regimes.

Figure 6 shows a meridional cross section of the monthly mean zonal mean zonal wind changes between $\left(\Delta \mathrm{O}_{3}-\mathrm{NH}\right)$ scenario and control run for November, December, 5 January and February. In November, the polar vortex accelerates by up to $5 \mathrm{~ms}^{-1}$. In December, the zonal mean zonal wind strongly weakens in mesospheric and upper stratospheric altitudes, while the polar night jet weakly accelerates below $10 \mathrm{hPa}$. There are changes in the zonal mean zonal wind from February to April, however, they are not statistically significant. It is also found that when a positive or negative anomaly 10 terminates in the lower stratosphere, another develops in the mesosphere, implying an oscillatory nature of the variability in the $\mathrm{NH}$ wintertime.

Figure 7 shows a meridional cross section of the monthly mean zonal mean zonal wind changes between $\left(\Delta \mathrm{O}_{3}-\mathrm{SH}\right)$ scenario and control run for May, July, August and October. The positive signal of temperature in late fall of $\mathrm{SH}$ stratosphere is coincident ${ }_{5}$ with a reduction of the zonal mean zonal wind. The zonal mean zonal wind anomalies show a strengthening from July to October. The ozone-perturbed zonal mean zonal wind anomalies have a positive anomaly of up to $2 \mathrm{~m} \mathrm{~s}^{-1}$ in the polar upper stratosphere and mesosphere in early winter. The maximum acceleration of the polar night jet in the $\mathrm{SH}$ occurrs in July and August, when an increase in the zonal mean zonal wind of up 20 to $6-7 \mathrm{~m} \mathrm{~s}^{-1}$ is found. As the winter progresses from July to October, the center of the zonal wind anomaly appears to shift poleward and downward with time. For instance, this signal extends from the middle troposphere to the upper stratosphere in October.

Generally, due to the lower ozone concentration in the $\left(\Delta \mathrm{O}_{3}-\mathrm{SH}\right)$ scenario, there is a cooling and an enhancement of the westerlies. But this does not work for the $\mathrm{NH}$ winter. This is what one would expect as the $\mathrm{SH}$ winter is less disturbed by planetary wave activity than the $\mathrm{NH}$ winter. The differences in temperature and zonal wind responses in July and January are a good motivation to study wave-mean flow interactions in the different scenarios. The simulated anomalies of both zonal mean temperature and zonal wind presented here suggest that some changes are very unlikely to be caused

\section{ACPD}

15, 33283-33329, 2015

Dynamical impact of energetic particles

K. Karami et al.

Title Page

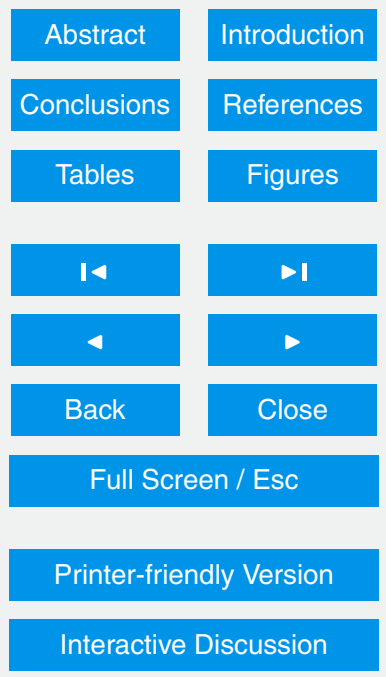

Interactive Discussion 
in-situ by ozone depletion and indirect dynamical feedbacks play a role. In other words, the initial changes in the radiative balance due to ozone depletion can affect the meridional temperature gradient and through thermal wind balance the vertical wind shear and hence the pattern of large-scale planetary wave propagation (see Fig. 8 . Since the 5 propagation of planetary waves is determined by the mean zonal wind condition (which can be altered by in-situ temperature changes due to imposed ozone depletion), and the background flow may, in turn, be changed through the deposition of zonal heat and momentum by planetary waves (Shiotani and Hirota, 1985), composite analyses are performed using wave related diagnostics.

\section{Wave-mean flow interaction diagnostics}

\subsection{Changes in the wave activity}

A vector quantity known as the Eliassen-Palm flux (EP flux) provides a useful tool for the description of small amplitude waves propagating in mean zonal shear flows. Each diagnostic vector has two components, where the meridional component is proportional to the momentum flux and the vertical componenet is proportional to the heat flux of quasi-geostrophic finite-amplitude waves. Its divergence represents wave-induced forcing of the mean flow in the transformed Eulerian-mean framework. In other words, the divergence of EP flux shows the zonal force per unit mass on the zonal mean flow by transient, non-conservative waves. In the transformed Eulerian mean formalism the non-acceleration theorem applies when the divergence of the EP flux is zero. The quasi-geostrophic EP flux $\left(F=\left(F_{\phi}, F_{p}\right)\right)$ in log pressure coordinats is defined by

$F=\left(F_{\phi}, F_{p}\right)=\left\{\begin{array}{l}F_{p}=\rho_{0} a f \cos (\phi) \frac{\overline{V^{\prime} \theta^{\prime}}}{\frac{\partial \bar{\theta}}{\partial p}} \\ F_{\phi}=-\rho_{0} a \cos (\phi) \overline{u^{\prime} V^{\prime}}\end{array}\right.$

Dynamical impact of energetic particles

K. Karami et al.

Title Page
Abstract

Conclusions

Tables

14

4

Back

Full Screen / Esc

Printer-friendly Version

Interactive Discussion
Close

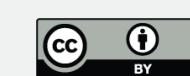


where the primes denote departures from the zonal mean and the overbars denote zonal means for any atmospheric variable. In Eq. (1), $u, v$ are zonal and meridional velocities, $\theta$ is potential temperature, $f=f(\phi)$ is the Coriolis parameter, $a$ is Earth's radius, $\phi$ is the latitude and $\rho_{0}$ is atmospheric density as a function of height. The vertical 5 derivative of the zonal-mean potential temperature $\frac{\partial \bar{\theta}}{\partial p}$ measures the static stability of the atmosphere and is negative for a statically stable atmosphere. The divergence of the EP flux vector is derived from the following equation:

$\nabla \cdot F=\frac{1}{a \cos (\phi)} \frac{\partial F_{\phi} \cos (\phi)}{\partial \phi}+\frac{\partial F_{p}}{\partial p}$

Positive values of EP flux divergence imply acceleration of the zonal flow, while neg10 the primary forcing in the deccelaration of the polar night jet of the $\mathrm{NH}$ in the winter time and spring time of the SH is the EP flux divergence. In other words, most of the departure from radiatively determined condition of the atmosphere can be explained by the divergence of EP flux (Monier and Weare, 2011). For more information about the transformed Eulerian mean formalism, the reader may refer to Edmon et al. (1980); Dunkerton et al. (1981).

Figure 9 shows the anomalies of the EP flux (arrows) and its divergences for $\left(\Delta \mathrm{O}_{3}\right.$ $\mathrm{NH}$ ) simulation. The positive differences (red contours) denote less convergence (zonal mean zonal wind acceleration) in the ozone-perturbed simulation compared to the control simulation, while negative differences (blue contours) denote more convergence of EP flux (decelaration of the zonal mean zonal wind) in the ozone-perturbed simulation. The regions shaded in green are significant, here the anomalies exceed the $\pm 3 \sigma$ interannual variability of the EP flux divergence derived from the control simulation. The contour interval is $1.0 \mathrm{~m} \mathrm{~s}^{-1}$ day $^{-1}$.

25 In November, positive anomalies of the EP flux divergence lead to an acceleration of the stratospheric flow. However in December and January, negative anomalies of the EP flux divergence decelerate the polar night jet. In February, wave-mean flow inter33295

\section{ACPD}

15, 33283-33329, 2015

Dynamical impact of energetic particles

K. Karami et al.

Title Page

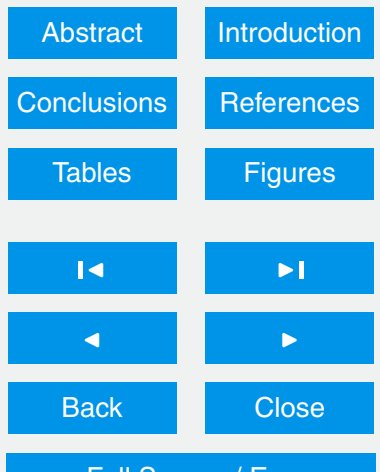

Full Screen / Esc

Printer-friendly Version

Interactive Discussion 
action acts to accelerate the polar vortex. In general, the acceleration of zonal winds corresponds with positive anomalies of the EP flux divergence and deceleration corresponds with negative values of this quantity. The results suggest that the oscillatory nature of the downward propagating signal seen in temperature and zonal wind (in the $5 \mathrm{NH}$ winter) is a consequence of interactions between the resolved waves in the model and the mean stratospheric flow. Therefore any change in the EP flux divergence leads to anomalies in the zonal mean zonal wind which in turn feeds back on the propagation of large scale disturbances from the troposphere to higher altitudes. It is also interesting to note that this oscillation in the stratospheric anomaly do not necessarily reflect oscil10 lating tropospheric forcing. For instance Yoden (1987); Holton and Dunkerton (1978); Holton and Mass (1976) found such oscillatory behavior in the stratospheric large scale waves even in the presence of steady forcing in the troposphere.

The same analyses for the $\left(\Delta \mathrm{O}_{3}-\mathrm{SH}\right)$ simulation is given in Fig. 10. In early wintertime of the $\mathrm{SH}$, negative anomalies of the EP flux divergence in the upper stratosphere 15 act to weaken the zonal mean zonal wind. However, the strong positive anomalies of the EP flux divergence accelerate the polar night jet in mid and late winter of the SH. The accelerated polar night jet of the $\mathrm{SH}$ acts to reflect the EP flux toward the equator.

The standard diagnostic tool to study the impact of the zonal flow on Rossby wave propagation is the refractive index of Rossby waves. The impact of the background atmospheric state on planetary wave propagation was first investigated by Charney and Drazin (1961) based on a linear wave theory. They found that vertical propagation of stationary planetary waves only happens when the zonal mean zonal wind is positive. Moreover, a strong stratospheric polar night jet (e.g. in the winter $\mathrm{SH}$ ) will block and reflect large scale waves. This implies that the zonal mean zonal wind should be weaker than a critical strength for vertical propagation. This theory also implies that larger waves (zonal wave number $=1,2,3$ ) have a better chance to exit from the troposphere and propagate into the stratosphere. In addition, the study of Shaw and Perlwitz (2013) shows the importance of the downward wave coupling between the stratosphere and troposphere for the development of tropospheric anomalies in midlatitudes. Moreover,

\section{ACPD}

15, 33283-33329, 2015
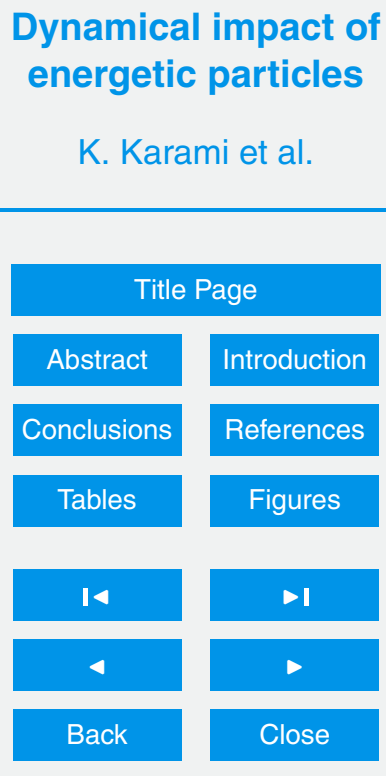

Full Screen / Esc

Printer-friendly Version

Interactive Discussion 
studies by Dickinson (1969); Matsuno (1970); Limpasuvan and Hartmann (2000); Hu and Tung (2002) not only affirmed the above-mentioned theory but also stressed the importance of vertical zonal wind shear, as well as the vertical gradient of the buoyancy frequency, for vertical propagation of large scale waves.

$n_{k}^{2}(y, z)=\frac{\overline{q_{\phi}}}{\bar{u}}-\left(\frac{k}{a \cos (\phi)}\right)^{2}-\left(\frac{f}{2 N H}\right)^{2}$

where

$\overline{q_{\phi}}=\frac{2 \Omega}{a} \cos (\phi)-\frac{1}{a^{2}} \frac{\partial}{\partial \phi}\left[\frac{\frac{\partial}{\partial \phi}[\bar{u} \cos (\phi)]}{\cos (\phi)}\right]+\left(\frac{f^{2}}{H N^{2}}+\frac{f^{2}}{N^{4}} \frac{\mathrm{d} N^{2}}{\mathrm{~d} z}\right) \frac{\partial \bar{u}}{\partial z}-\frac{f^{2}}{N^{2}} \frac{\partial^{2} \bar{u}}{\partial z^{2}}$

is the meridional gradient of the zonal mean potential vorticity which is a fundamental 10 et al., 1987). Here $H$ is the scale height, $k$ is zonal wave number and $\Omega$ is the Earth's rotation frequency.

While the refractive index is an easy to use diagnostic tool, it is not ideally suited for averaging, e.g. mean climatological values can be misleading. As shown by Li et al. ficult to study the climatological state of the background flow for planetary wave propagation. In calculating the climatology of the refractive index squared, the problem arises from averaging over times (within a month) of positive and negative values at the same location. Such cancellation between time periods makes the interpretation of climatological states difficult. Therefore Karami et al. (2015) investigated the above-mentioned problem and suggested a novel modification to the diagnostic tool introduced by Li et al. (2007), which is better suited to study the climatology of atmospheric background conditions for Rossby wave propagation. This metric, the so-called Probability of Favorable Propagation Conditions for Rossby Waves (PFPCRW), estimates the likelihood for sta-

tionary planetary waves to propagate from one region to another at any time, altitude

ACPD

15, 33283-33329, 2015

Dynamical impact of energetic particles

K. Karami et al.

Title Page
Abstract

Conclusions

Tables

14

4

Back

Full Screen / Esc

Printer-friendly Version

Interactive Discussion $\checkmark$

Close

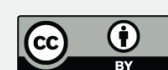


and latitude in a climatological sense. Higher values of this quantity provide a window of opportunity for planetary waves to propagate. Likewise, smaller values of this quantity highlight areas where Rossby waves tend to propagate away from. The climatology of this quantity for different zonal and meridional wave numbers in NCEP/NCAR 5 reanalysis data is presented in Karami et al. (2015).

Figures 11 and 12 show the anomalies of the probability of favourable condition for Rossby wave propagation for $\left(\Delta \mathrm{O}_{3}-\mathrm{NH}\right)$ and $\left(\Delta \mathrm{O}_{3}-\mathrm{SH}\right)$ simulations, respectively. Significant changes in the PFPCRW can be seen. The black contours show regions that have an enhanced probability of Rossby wave propagation and the red lines show regions that have decreased probability of Rossby wave propagation.

In early winter (November-December) of the $\mathrm{NH}$, there is an enhancement of PFPCRW poleward of $50^{\circ} \mathrm{N}$. At the same time, a reduction of PFPCRW is found equatorward of $50^{\circ} \mathrm{N}$. These changes are particularly important since they can result in changes in the frequency of SSW in January and February. In midwinter of the $\mathrm{NH}$ 15 (January and February) there is a reduction in PFPCRW around the polar night jet region and an enhancement is found equatorward of $40^{\circ} \mathrm{N}$.

In May, poleward of $50^{\circ} \mathrm{S}$ of stratospheric heights, there is an enhancement of wave propagation chance and equatorward of it, there is reduction of wave propagation possibility for $Z W N=1$. We also found an enhancement of wave propagation possibility for $\mathrm{ZWN}=1$ around $100 \mathrm{hPa}$, in May. From July to October, there is a reduction of wave propagation possibility around the polar night jet and an enhancement of wave propagation chances equatorward of $50^{\circ} \mathrm{S}$. During the $\mathrm{SH}$ wintertime, the ozone depletion in the stratosphere leads to a relative cooling of the polar vortex region and hence an enhanced meridional temperature gradient which in turn accelerates the polar vortex.

25 The strengthened polar night jet of the SH has more capability to block wave activity from high latitudes and enhances their refraction toward the equator. This results are consistent with the Seppälä et al. (2013) result which suggests higher geomagnetic activities (in the absence of SSW) lead to an enhancement of planetary wave refraction toward the equator when geomagnetic activity is higher than average.

\section{ACPD}

15, 33283-33329, 2015

Dynamical impact of energetic particles

K. Karami et al.

Title Page

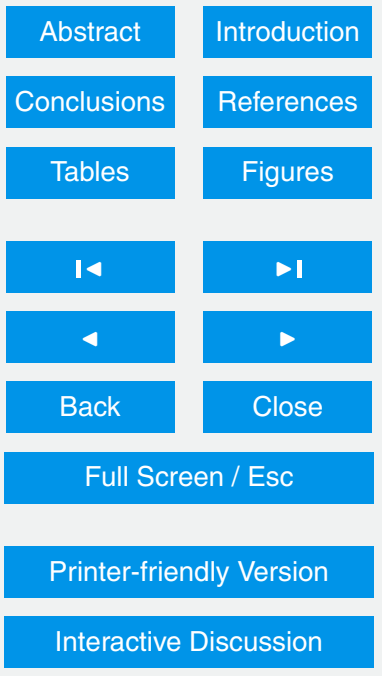


In late wintertime of both hemispheres the signal of changes reach to tropospheric heights (below $100 \mathrm{hPa}$ ). This feature is more pronounced in $\mathrm{NH}$ spring time. The differences for $Z W N=2,3$ also show the same behaviour as $Z W N=1$ (not shown). From Eqs. (3) and (4) it can be seen that the refractive index squared could be altered by 5 atmospheric zonal flow $(\bar{u})$, vertical shear of zonal mean zonal wind $\left(\frac{\partial u}{\partial z}\right)$, quadratic vertical shear of zonal mean zonal wind $\left(\frac{\partial^{2} \bar{u}}{\partial z^{2}}\right)$ and atmospheric stability $\left(N^{2}(y, z)\right)$. In the study of Chen and Robinson (1992) the tropopause acts like a valve for the propagation of Rossby waves from the troposphere to the stratosphere. They suggested that the key parameters that control the valve are the vertical gradient of buoyancy 10 frequency and the vertical shear of the zonal winds at the tropopause region. They suggested that the larger gradient of the buoyancy frequency reduces the propagation of Rossby waves from troposphere to the stratosphere. They also showed that the less the vertical wind shear, the more wave activity can penetrate into the stratosphere. By changing the above mentioned parameters, the stratosphere plays an active role in the

15 tropospheric variability and can determine, to a certain degree, its own budget of wave activity.

\subsection{Changes in the frequency of sudden stratospheric warmings and stratospheric final warming dates due to the ozone depletion scenarios}

It is widely accepted that Sudden Stratospheric Warming (SSW) events are one of the most intense manifestation of the two-way coupling of the stratosphere-troposphere system in the $\mathrm{NH}$. In the $\mathrm{SH}$, SSWs rarely occur, due to less quasi-stationary largescale waves (van Loon and Jenne, 1972). Generally, enhanced wave activity flux from the troposphere to the stratosphere and internal dynamical processes resulting in nonlinear interaction of planetary waves and mean flow at the stratospheric heights are contributing factors to the occurrence of SSW in the NH (Palmer, 1981).

Due to the importance of SSW occurrence for stratospheric and tropospheric circulation, we investigate the modification of the frequency and timing of SSWs due to the
ACPD

15, 33283-33329, 2015

Dynamical impact of energetic particles

K. Karami et al.

Title Page

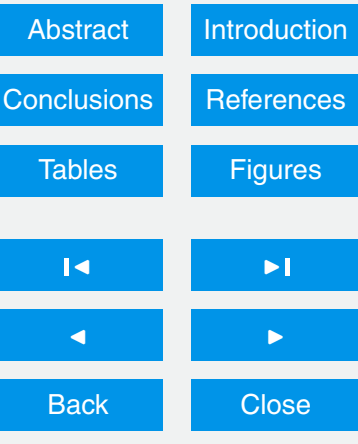

Full Screen / Esc

Printer-friendly Version

Interactive Discussion 
imposed ozone perturbation. Moreover, since a key component of stratospheric and tropospheric variability in spring and summer of the $\mathrm{SH}$ is driven by the Stratospheric Final Warming Dates (SFWDs) of the polar vortex (Wilcox and Perez, 2013), we further investigate any possible changes in the final warming date of the polar vortex due to 5 the imposed ozone perturbation in the $\mathrm{SH}$.

There are numerous definitions for a SSW to be called major or minor (Kuttippurath and Nikulin, 2012). According to Mclnturff (1978) a major warming is classified as a thermal pulse increasing poleward of $60^{\circ} \mathrm{N}$ and followed by a reversal of the prevailing westerly wind to easterly at $10 \mathrm{hPa}$ in $60^{\circ} \mathrm{N}$. An increase in the temperature 10 of at least $25^{\circ} \mathrm{C}$ in a period of about a week or even less at any stratospheric height of the winter hemisphere followed by the deceleration of the polar night jet is characterised as a minor warming. Since after an onset of a SSW, the zonal mean zonal winds might fluctuate between positive (westerly) and negative (easterly) values, one might implement a criterion to avoid counting a SSW as twice (Charlton and Polvani,

2007). Once a SSW is identified, no SSW within 3 weeks of the date of it can be defined as a SSW. This time interval is approximately equal to twice of the stratospheric thermal damping time at $10 \mathrm{hPa}$ (Newman and Rosenfield, 1997). In late winter or early spring when the polar night vortex breaks down, the transition state of the zonal mean zonal wind changes from westerlies to easterlies. This transition is usually accompanied by an abrupt temperature increase inside of the polar vortex and is known as SFWD (Waugh et al., 1999; Black and McDaniel, 2007a, b). In contrast to the occurrence of the SSW events (0.6 events per year; Charlton and Polvani, 2007), SFWD take place every spring in both hemispheres and hence are more frequent than SSW. Following Charlton et al. (2007) a SFWD is defined as the final time when the zonal mean zonal wind at the central latitude of the westerly polar jet drops below zero and never recovers to a specified positive threshold value (with thresholds of 5 and $10 \mathrm{~m} \mathrm{~s}^{-1}$ of the $\mathrm{NH}$ and $\mathrm{SH}$, respectively) until the subsequent autumn. Figure 13 demonstrates the frequency of SSWs in early winter $(E-W)$, midwinter $(M-W)$ and late winter $(L-W)$. 1 November to 15 December is defined as early winter, 16 December to 15 February

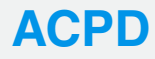

15, 33283-33329, 2015

Dynamical impact of energetic particles

K. Karami et al.

Title Page

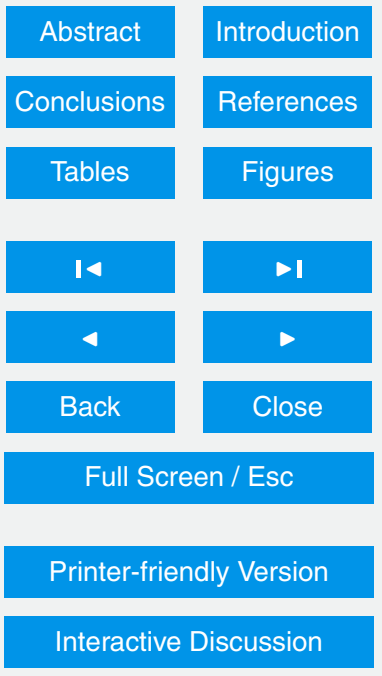


is considered as midwinter and 16 February to the end of March is late wintertime. The vertical axis describes the frequency of events per year in a given period. Gray and black bars show the frequency of SSWs for control and perturbed simulations respectively. Too many events in early winter compared to the observations (Charlton and 5 Polvani, 2007) are found for the control simulation. This bias has also been reported in other models that have deployed ECHAM5 as atmospheric base model and might be linked to an anomalous tropospheric forcing (Charlton et al., 2007; Ayarzagüena et al., 2013). The frequency of SSW occurrence for the control simulation is 0.65 events per year, while the distribution of SSW for the ozone-perturbed simulation is about 0.69.

10 This suggests that the frequency of SSW has not changed significantly. However, a shift of their timing toward mid and late winter is detected. The changes in the occurrence of SSW is more than $3 \sigma$ significant in early and late winter and about $2 \sigma$ in midwinter.

Dates of stratospheric final warmings are calculated using the same method as that of Black and McDaniel (2007a, b). In this method zonal mean zonal winds at $60^{\circ} \mathrm{S}$ are 15 first smoothed using a 5 day low-pass filter ( 5 day running averages of daily zonal wind) and then warmings are identified when the smoothed winds first drop below $10 \mathrm{~m} \mathrm{~s}^{-1}$ at $50 \mathrm{hPa}$ and remain below that threshold until the following winter. It is worthwhile to mention that in some years (about $5 \%$ in our simulation), the zonal mean zonal winds never become westward. These years are ignored in our analysis. The mean date of the stratospheric final warming in the $\mathrm{SH}$ for the control simulation is 13 November with a standard deviation of about 22.8 days (error of the mean equals to 2.28 days), while for ozone-perturbed simulation the mean date of SFWD is 26 November (two weeks difference in the occurrence of SFWDs).

\section{Ozone-induced climate variation due to 11 year solar UV variability}

25 Solar UV variations are increasingly considered as a potentially important source of stratospheric variability (Hood, 2004). In this section the impact of an ozone anomaly of about $4 \%$ at the tropical stratopause due to the 11 year solar cycle on middle at-

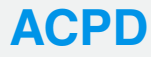

15, 33283-33329, 2015

Dynamical impact of energetic particles

K. Karami et al.

Title Page

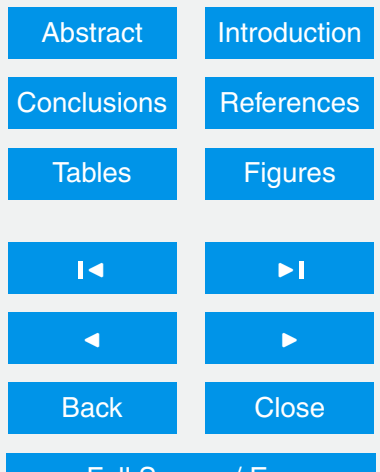

Full Screen / Esc

Printer-friendly Version

Interactive Discussion 
mospheric dynamic and temperature is investigated and the magnitude of the changes are compared to the changes originated by ozone changes due to high energy particle precipitation's effect. Similar to Sect. 4, composite analyses are performed to detect the impact of imposed ozone loss on temperature and zonal wind. The multi-year monthly 5 means of zonally averaged values for both zonal wind and temperature are used to compare the differences between the control simulation and ozone-perturbed simulation.

Figure 14 shows a meridional cross section of the monthly mean temperature changes between the $\left(\Delta \mathrm{O}_{3}\right.$-TS) scenario and the control simulation. Contour values show the monthly mean zonal mean of temperature differences between the ozoneperturbed and the control simulation and shaded areas denote the level of significance. The contour interval is $1 \mathrm{~K}$. A local cooling of the tropical stratopause is expected. However, this cooling is less than $-1 \mathrm{~K}$ in November. A positive temperature signal which is about $3 \mathrm{~K}$ develops in the $\mathrm{NH}$ polar mesosphere. However, the upper and middle 15 stratosphere show a statistically significant cooling effect. As NH winter progresses from December to March the mesospheric positive signal moves downward with time. However the magnitudes and the significances of this positive anomaly are not constant over time. The same is also true for the negative temperature signal of polar latitudes. A negative temperature signal of about $-2 \mathrm{~K}$ develops at polar region of $\mathrm{NH}$ mesosphere in December. As winter progresses this negative signal moves downward, reaching to tropospheric altitudes in March. A local temperature cooling of about $-1 \mathrm{~K}$ is evident over tropical stratopause in January.

In the $\mathrm{SH}$ a positive temperature signal of about $1 \mathrm{~K}$ in the mesospheric polar region and a negative temperature signal with similar magnitude in stratospheric polar region develope in April. As time progresses the mesospheric positive signal moves downward, reaching to stratospheric altitudes in May and a significant negative signal is substituted for positive temperature signal in mesospheric altitudes. This negative signal moves downward in June. However, after June (July-September) the magnitude of the temperature signal in polar regions of the $\mathrm{SH}$ is negligible.
ACPD

15, 33283-33329, 2015

Dynamical impact of energetic particles

K. Karami et al.

Title Page

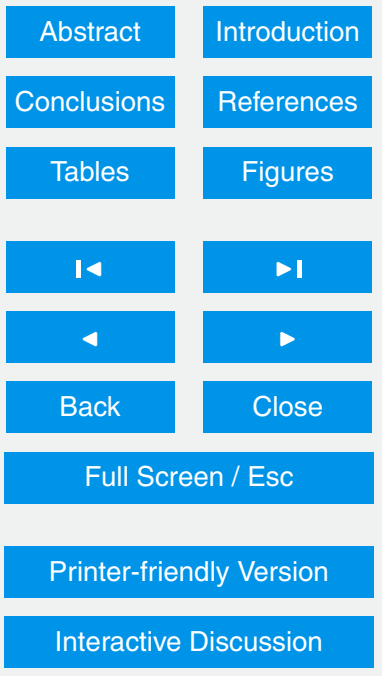


Figure 15 shows a meridional cross section of the monthly mean zonal mean zonal wind changes between $\left(\Delta \mathrm{O}_{3}\right.$-TS) scenario and control simulation. A positive zonal mean zonal wind signal that develops in tropical mesosphere of $\mathrm{NH}$ moves poleward and downward from December to April. The poleward and downward propagation of 5 zonal mean zonal wind signal from early winter to late winter was previously reported by Kodera and Kuroda (2002). From July to October, there are small changes in the zonal wind in $\mathrm{SH}$. The unaffected winter of the $\mathrm{SH}$ suggests that in midwinter of the $\mathrm{SH}$ the polar vortex is too strong to be affected significantly by $4 \%$ ozone changes over the tropical stratopause. Moreover, the magnitudes of both zonal mean zonal wind and temperature differences between ozon-perturbed and control simulation suggest that in many cases the magnitudes of theses responses in the case of ozone perturbation due to high energy particle precipitation could exceed (or at least comparable) the responses of ozone changes due to the 11 year cycle UV variability. It is also interesting to mention that in our simulation, mesospheric-upper stratospheric temperature anomalies tend to move downward due to $\left(\Delta \mathrm{O}_{3}-\mathrm{TS}\right)$ scenario or $\left(\Delta \mathrm{O}_{3}-\mathrm{NH}\right) /\left(\Delta \mathrm{O}_{3}-\mathrm{SH}\right)$ scenarios.

\section{Conclusions}

Here, we determine the influence of changed ozone concentrations (typical for high energy particle precipitation events) on middle atmospheric temperature and circulation. Several long time-slice simulations were carried with a free-running version of the EMAC model with prescribed ozone climatologies. The following conclusions are derived from our analyses:

a. The direct radiative impact of wintertime ozone depletion inside the polar vortex shows that the strongest short wave heating rate changes occur in the upper stratosphere and stratopause region and short wave heating rate differences between the control run and ozone-perturbed scenarios vanish at the terminator.
ACPD

15, 33283-33329, 2015

Dynamical impact of energetic particles

K. Karami et al.

Title Page

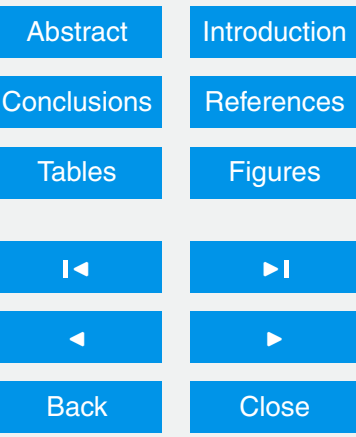

Full Screen / Esc

Printer-friendly Version

Interactive Discussion 
The net effect of ozone depletion in all affected area, is local cooling. However, in the upper stratosphere and mesospheric altitudes, enhanced absorption of solar radiation, which has not been absorbed above due to ozone loss, have result in local heating.

b. Contrary to the cooling effect of imposed ozone depletion due to less short wave absorption, the long wave heating rate changes show opposite behavior above and below of approximately the stratopause. In the upper stratosphere and mesosphere, less ozone leads to a relative warming. Since in these altitudes ozone locally emits long wave radiation and cools the atmosphere, less cooling due to less ozone will result in a relative warming effect.

c. The polar night jet of the $\mathrm{SH}$ accelerates and inside of the polar vortex region gets cooler according to the $\left(\Delta \mathrm{O}_{3}-\mathrm{SH}\right)$ scenario. This cooling is interpreted as the direct radiative impact of ozone depletion inside of the $\mathrm{SH}$ polar vortex. In the $\mathrm{NH}$ the temperature signals vary from month to month and move downward from mesospheric/upper stratospheric heights to the tropospheric altitudes.

d. Analysis of the EP flux divergence reveals the nature of the oscillatory mode in the downwelling signal of temperature and zonal wind. Since the strengthened or weakened zonal wind is in harmony with positive and negative anomalies of the EP flux divergence respectively, we suggest that any change in the EP flux divergence leads to anomalies in the zonal mean zonal wind which in turn feeds back on the propagation of Rossby waves.

e. Simulated anomalies of both zonal mean temperature and zonal wind suggest that changes in both parameters are very unlikely to be caused in situ by ozone depletion and indirect dynamical conditions play a great role in the $\mathrm{NH}$. However in the $\mathrm{SH}$ most anomalies are expected from the direct thermal impact of ozone loss.

\section{ACPD}

15, 33283-33329, 2015

Dynamical impact of energetic particles

K. Karami et al.

\section{Title Page}

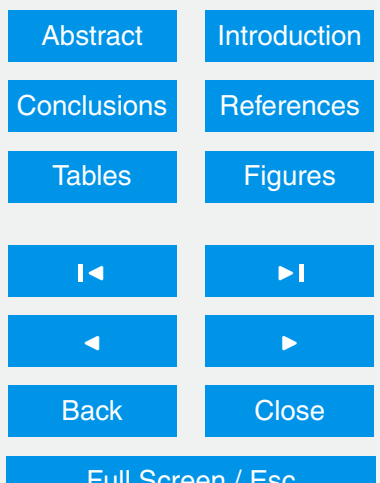

Full Screen / Esc

Printer-friendly Version

Interactive Discussion 
f. The frequency of SSW occurrence for the control simulation is 0.65 events per year, while the distribution of the SSWs for the ozone-perturbed simulation is about 0.69 . This suggests that the frequency of SSWs has not changed significantly. However, a shift of their timing toward mid and late winter is detected. One possible explanation of this shift of sudden SSWs toward the midwinter are changes in the enhancement of wave propagation in November and December. Moreover, the mean date of the stratospheric final warming in the $\mathrm{SH}$ for the control simulation is 13 November with the standard deviation of about 22.8 days (error of the mean equals to 2.28 days), while for ozone-perturbed simulation the mean date of SFWD is 26 November.

g. Analyses of changes of the probability of favourable propagation conditions of Rossby waves suggest that changes in the ozone concentration in stratospheric and mesospheric heights have the capability to alter the propagation condition of Rossby waves. The signal of changes in this quantity can reach to tropospheric

While the influence of the EPP on the variability of the strength of the stratospheric westerly flow is discussed in this paper, however the full extent of stratospheretroposphere connection (tropospheric response) requires considering the tropospheric eddy feedback (a process that the its details are not well understood).
ACPD

15, 33283-33329, 2015

Dynamical impact of energetic particles

K. Karami et al.

Title Page

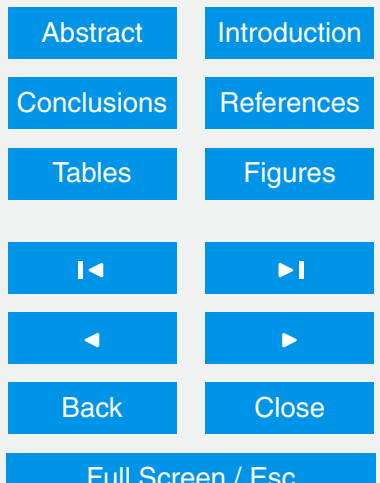

Full Screen / Esc

Printer-friendly Version

Interactive Discussion 
Acknowledgements. Khalil Karami would like to thank Thomas Reddmann, BjörnMartin Sinnhuber and Alexey Vlasov for their helpful comments and disscussions during the time which this research was carried out. Khalil Karami and Miriam Sinnhuber gratefully acknowledge funding by the Helmholtz Society within the Helmholtz Young Investigators 5 group: Solar variability, climate, and the role of the mesosphere/lower thermosphere, project NWG-642. We also acknowledge support by Deutsche Forschungsgemeinschaft and Open Access Publishing Fund of Karlsruhe Institute of Technology.

The article processing charges for this open-access publication were covered

\section{References}

Andersson, M. E., Verronen, P. T., Rodger, C. J., Clilverd, M. A., and Seppälä, A.: Missing driver in the Sun-Earth connection from energetic electron precipitation impacts mesospheric ozone, Nature Commun., 5, 5197, doi:10.1038/ncomms6197, 2014. 33286

15 Andrews, D. G., Leovy, C. B., and Holton, J. R.: Middle Atmosphere Dynamics, Academic Press, San Diego, 1987. 33297

Ayarzagüena, B., Langematz, U., Meul, S., Oberländer, S., Abalichin, J., and Kubin, A.: The role of climate change and ozone recovery for the future timing of Major Stratospheric Warmings, Geophys. Res. Lett., 40, 2460-2465, doi:10.1002/grl.50477, 2013. 33301

Baldwin, M. P. and Dunkerton, T. J.: Stratospheric harbingers of anomalous Weather Regimes, Science, 294, 581-584, 2001. 33292

Baumgaertner, A. J. G., Seppälä, A., Jöckel, P., and Clilverd, M. A.: Geomagnetic activity related $\mathrm{NO}_{x}$ enhancements and polar surface air temperature variability in a chemistry climate model: modulation of the NAM index, Atmos. Chem. Phys., 11, 4521-4531, doi:10.5194/acp11-4521-2011, 2011. 33286, 33287, 33292

Black, R. X. and McDaniel, B.: Interannual variability in the Southern Hemisphere circulation organized by stratospheric final warming events, J. Atmos. Sci., 64, 2968-2975, 2007a. 33300, 33301

Black, R. X. and McDaniel, B.: The dynamics of Northern Hemisphere stratospheric final warming events, J. Atmos. Sci., 64, 2932-2946, 2007b. 33300, 33301

\section{ACPD}

15, 33283-33329, 2015

Dynamical impact of energetic particles

K. Karami et al.

Title Page
Abstract

Conclusions

Tables

14

4

Back

Printer-friendly Version

Interactive Discussion
>

Close

\section{Full Screen / Esc}

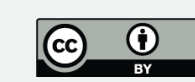


Braesicke, P. and Pyle, J. A.: Changing ozone and changing circulation in northern midlatitudes: Possible feedbacks?, Geophys. Res. Lett., 30, 1059, doi:10.1029/2002GL015973, 2003. 33286

Brasseur, G.: Aeronomy of the Middle Atmosphere, Chemistry and Physics of the Stratosphere and Mesosphere, Springer US, 2005. 33290

Charlton, A. J. and Polvani, L. M.: A new look at stratospheric sudden warmings, part I: climatology and modeling benchmarks, J. Climate, 20, 449-469, 2007. 33300, 33301

Charlton, A. J., Polvani, L. M., Perlwitz, J., Sassi, F., Manzini, E., Shibata, K., Pawson, S., Nielsen, J. E., and Rind, D.: A new look at stratospheric sudden warmings, part II: evaluation of numerical model simulations, J. Climate, 20, 470-488, 2007. 33300, 33301

Charney, J. G. and Drazin, P. G.: Propagation of planetary scale disturbances from the lower into the upper atmosphere, J. Geophys. Res., 66, 83-109, 1961. 33296

Chen, P. C. and Robinson, W. A.: propagation of planetary waves between the troposphere and stratosphere, J. Atmos. Sci., 49, 2533-2545, 1992. 33299

Christiansen, B., Guldberg, A., Hansen, A. W., and Riishojgaard, L. P.: On the response of a three-dimensional general circulation model to imposed changes in the ozone distribution, $\mathrm{J}$. Geophys. Res., 102, 13051-13077, 1997. 33286

Dickinson, R. E.: Planetary Rossby waves propagating vertically through weak westerly wind wave guides, J. Atmos. Sci., 25, 984-1002, 1969. 33297

20

Dunkerton, T. J., Hsu, C. P. F., and McIntyre, M. E.: Some Eulerian and Lagrangian diagnostics for a model stratospheric warming, J. Atmos. Sci., 38, 819-843, 1981. 33295

Edmon, H. J., Hoskins, J. B. J., and McIntyre, M. E.: Eliassen-Palm cross sections for the troposphere, J. Atmos. Sci., 37, 2600-2616, 1980. 33295

Fortuin, J. P. F. and Langematz, U.: An update on the global ozone climatology and on concurrent ozone and temperature trends, SPIE Atmos. Sens. Model., 2311, 207-216, 1994. 33289

Fouquart, Y. and Bonnel, B.: Computation of solar heating of the Earth's atmosphere: a new parameterization, Beitraege zur Physik der Atmosphaere, 53, 35-62, 1980. 33288

Funke, B., López-Puertas, M., Gil-Lopez, S., Clarmann, T. V., Stiller, G., Fischer, H., and Kellmann, S.: Downward transport of upper atmospheric $\mathrm{NO}_{x}$ into the polar stratosphere and lower mesosphere during the Antarctic 2003 and Arctic 2002/2003 winters, J. Geophys. Res., 110, D24308, doi:10.1029/2005JD006463, 2005. 33286

\section{ACPD}

15, 33283-33329, 2015

Dynamical impact of energetic particles

K. Karami et al.

Title Page

Abstract

Introduction

Conclusions

References

Tables

Figures

14

$>1$

4

Back

$>$

Close

Full Screen / Esc

Printer-friendly Version

Interactive Discussion 
Funke, B., López-Puertas, M., Stiller, G. P., and Clarmann, T. V.: Mesospheric and stratospheric $\mathrm{NO}_{y}$ produced by energetic particle precipitation during 2002-2012, J. Geophys. Res., 119, 4429-4446, 2014. 33285

Fytterer, T., Mlynczak, M. G., Nieder, H., Pérot, K., Sinnhuber, M., Stiller, G., and Urban, J.: Energetic particle induced intra-seasonal variability of ozone inside the Antarctic polar vortex observed in satellite data, Atmos. Chem. Phys., 15, 3327-3338, doi:10.5194/acp-15-33272015, 2015. 33287, 33289

Holton, J. R. and Dunkerton, T.: On the Role of wave transience and dissipation in stratospheric mean flow vacillations, J. Atmos. Sci., 35, 740-744, 1978. 33296

10 Holton, J. R. and Mass, C.: Stratospheric vacillation cycles, J. Atmos. Sci., 33, 2218-2225, 1976. 33296

Hood, L.: Effects of solar UV variability on the stratosphere, in Solar Variability and Its Effect on the Earth's Atmospheric and Climate System, AGU Monogr. Ser., edited by: Pap, J. et al., AGU, Washington, D.C., 2002. 33301

$\mathrm{Hu}, \mathrm{Y}$. and Tung, K. K.: Interannual and decadal variations of planetary wave activity, stratospheric cooling, and northern hemisphere annular mode, J. Climate, 15, 1659-1673, 2002. 33297

Jackman, C. H., Fleming, E. L., and Vitt, F. M.: Influence of extremely large solar proton events in a changing stratosphere, J. Geophys. Res., 11, 659-670, 2000. 33286

20

Jackman, C. H., Roble, R. G., and Fleming, E. L.: Mesospheric dynamical changes induced by the solar proton events in October-November 2003, Geophys. Res. Lett., 34, L04812, doi:10.1029/2006GL028328, 2007. 33285

Jöckel, P., Tost, H., Pozzer, A., Brühl, C., Buchholz, J., Ganzeveld, L., Hoor, P., Kerkweg, A., Lawrence, M. G., Sander, R., Steil, B., Stiller, G., Tanarhte, M., Taraborrelli, D., van Aardenne, J., and Lelieveld, J.: The atmospheric chemistry general circulation model ECHAM5/MESSy1: consistent simulation of ozone from the surface to the mesosphere, Atmos. Chem. Phys., 6, 5067-5104, doi:10.5194/acp-6-5067-2006, 2006. 33287, 33288

Karami, K., Ghader, S., Bidokhti, A. A., Joghataei, M., Neyestani, A., and Mohammadabadi, A.: Planetary and tidal wave-type oscillations in the ionospheric sporadic $E$ layers over Tehran region, J. Geophys. Res., 117, A04313, doi:10.1029/2011JA017466, 2012. 33290

Karami, K., Braesicke, P., Sinnhuber, M., and Versick, S.: On the climatological probability of the vertical propagation of stationary planetary waves, Atmos. Chem. Phys. Discuss., 15, 32289-32321, doi:10.5194/acpd-15-32289-2015, 2015. 33297, 33298
ACPD

15, 33283-33329, 2015

Dynamical impact of energetic particles

K. Karami et al.

Title Page

Abstract

Introduction

Conclusions

References

Tables

Figures

14

$>1$

4

Back

Close

Full Screen / Esc

Printer-friendly Version

Interactive Discussion 
Kiehl, J. T. and Boville, B. A.: The radiative-dynamical response of a stratospheric-tropospheric general circulation model to changes in ozone, J. Atmos. Sci., 45, 1798-1817, 1988. 33286

Kodera, K. and Kuroda, Y.: Dynamical response to the solar cycle: winter stratopause and lower stratosphere, J. Geophys. Res., 107, 4749, doi:10.1029/2002JD002224, 2002. 33303

5 Kuttippurath, J. and Nikulin, G.: A comparative study of the major sudden stratospheric warmings in the Arctic winters 2003/2004-2009/2010, Atmos. Chem. Phys., 12, 8115-8129, doi:10.5194/acp-12-8115-2012, 2012. 33300

Langematz, U., Kunze, M., Krüger, K., Labitzke, K., and Roff, G. L.: Thermal and dynamical changes of the stratosphere since 1979 and their link to ozone and $\mathrm{CO}_{2}$ changes, J. Geophys. Res., 108, 4027, doi:10.1029/2002JD002069, 2003. 33286, 33290

Langematz, U., Grenfell, J. L., Matthes, K., Mieth, P., Kunze, M., Steil, B., and Brühl, C.: Chemical effects in 11-year solar cycle simulations with the Freie Universitat Berlin Climate Middle Atmosphere Model with online chemistry (FUB-CMAM-CHEM), Geophys. Res. Lett, 32, L13803, doi:10.1029/2005GL022686, 2005. 33286

15 Lean, J., Rottman, G., Kyle, H., Woods, T., Hickey, J., and Puga, L.: Detection and parameterisation of variations in solar midand near-ultraviolet radiation $(200-400 \mathrm{~nm})$, J. Geophys. Res., 102, 29939-29956, 1997. 33286

Li, Q., Graf, H.-F., and Giorgetta, M. A.: Stationary planetary wave propagation in Northern Hemisphere winter - climatological analysis of the refractive index, Atmos. Chem. Phys., 7,

$20 \quad$ 183-200, doi:10.5194/acp-7-183-2007, 2007. 33297

Limpasuvan, V. and Hartmann, D. L.: Wave-maintained annular modes of climate variability, J. Climate, 13, 4414-4429, 2000. 33297

Lu, H., Clilverd, M. A., Seppälä, A., and Hood, L. L.: Geomagnetic perturbations on stratospheric circulation in late winter and spring, J. Geophys. Res., 113, D16106, doi:10.1029/2007JD008915, 2008. 33287

Marsh, D. R., Garcia, R. R., Kinnison, D. E., Boville, B. A., Sassi, F., Solomon, S. C., and Matthes, K.: Modeling the whole atmosphere response to solar cycle changes in radiative and geomagnetic forcing, J. Geophys. Res., 112, D23306, doi:10.1029/2006JD008306, 2007. 33286

30 Matsuno, T.: Vertical propagation of stationary planetary waves in the winter Northern Hemisphere, J. Atmos. Sci., 27, 871-883, 1970. 33297

Mclnturff, R. M.: Stratospheric warmings: Synoptic, dynamic and general-circulation aspects, Tech. Rep., NASA-RP-1017, NASA Reference Publ., Washington D.C., USA, 1978. 33300
ACPD

15, 33283-33329, 2015

Dynamical impact of energetic particles

K. Karami et al.

Title Page

Abstract

Introduction

Conclusions

References

Tables

Figures

14

$>1$

4

Back

$>$

Close

Full Screen / Esc

Printer-friendly Version

Interactive Discussion 
Mlawer, E. J., Taubman, S. J., Brown, P. D., lacono, M. J., and Clough, S. A.: Radiative transfer for inhomogeneous atmospheres: RRTM, a validated correlated-k model for the longwave, J. Geophys. Res, 102, 16663-16682, doi:10.1029/97JD00237, 1997. 33288

Monier, E. and Weare, B. C.: Climatology and trends in the forcing of the stratospheric zonal5 mean flow, Atmos. Chem. Phys., 11, 12751-12771, doi:10.5194/acp-11-12751-2011, 2011. 33295

Newman, P. A. and Rosenfield, J. E.: Stratospheric thermal damping times, Geophys. Res. Lett., 24, 433-436, 1997. 33300

Nissen, K. M., Matthes, K., Langematz, U., and Mayer, B.: Towards a better representation of the solar cycle in general circulation models, Atmos. Chem. Phys., 7, 5391-5400, doi:10.5194/acp-7-5391-2007, 2007. 33289

Päivärinta, S. M., Seppälä, A., Andersson, M. E., Verronen, P. T., Thölix, L., and Kyrölä, E.: Observed effects of solar proton events and sudden stratospheric warmings on odd nitrogen and ozone in the polar middle atmosphere, J. Geophys. Res., 118, 6837-6848, 2013. 33286

Palmer, T. N.: Diagnostic study of a wavenumber, 2, Stratospheric sudden warming in a transformed Eulerian-mean formalism, J. Atmos. Sci., 38, 844-855, 1981. 33299

Randall, C. E., Rusch, D. W., Bevilacqua, R. M., Hoppel, K. W., and Lumpe, J. D.: Polar ozone and aerosol meausurement (POAM) II stratospheric $\mathrm{NO}_{2}$, 1993-1996, J. Geophys. Res., 28, 361-371, 1998. 33286

20 Randall, C. E., Harvey, V. L., Manney, G. L., Orsolini, Y., Codrescu, M., Sioris, C., Brohede, S., Haley, C. S., Gordley, L. L., Zawodny, J. M., and Russell, J. M.: Stratospheric effects of energetic particle precipitation in 2003-2004, Geophys. Res. Lett., 32, L05802, doi:10.1029/2004GL022003, 2005. 33287

Randall, C. E., Harvey, V. L., Siskind, D. E., France, J., Bernath, P. F., Boone, C. D., and Walker, K. A.: $\mathrm{NO}_{x}$ descent in the Arctic middle atmosphere in early 2009, Geophys. Res. Lett., 36, L18811, doi:10.1029/2009GL039706, 2009. 33285

Roeckner, E., Brokopf, R., Esch, M., Giorgetta, M., Hagemann, S., Kornblueh, L., Manzini, E., Schlese, U., and Schulzweida, U.: The atmospheric general circulation model ECHAM5. PART II: Sensitivity of Simulated Climate to Horizontal and Vertical Resolution, Geophysical 30 Research Letters, Tech. rep., Max Planck Institute for Meteorology, MPI-Report 354, 2004. 33287,33288

\section{ACPD}

15, 33283-33329, 2015

Dynamical impact of energetic particles

K. Karami et al.

Title Page

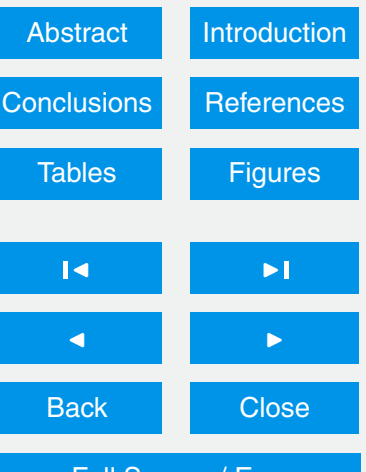

Full Screen / Esc

Printer-friendly Version

Interactive Discussion 
Rozanov, E., Callis, L., Schlesinger, M., Yang, F., Andronova, N., and Zubov, V.: Atmospheric response to $\mathrm{NO}_{y}$ source due to energetic electron precipitation, Geophys. Res. Lett., 32, L14811, doi:10.1029/2005GL023041, 2005. 33286, 33292

Seppälä, A., Verronen, P. T., Kyrölä, E., Hassinen, S., Backman, L., Hauchecorne, A., Bertaux, J. L., and Fussen, D.: Solar proton events of October-November 2003: Ozone depletion in the Northern Hemisphere polar winter as seen by GOMOS/Envisat, Geophys. Res. Lett., 31, L19107, doi:10.1029/2004GL021042, 2004. 33286

Seppälä, A., Randall, C. E., Clilverd, M. A., Rozanov, E., and Rodger, C. J.: Geomagnetic activity and polar surface air temperature variability, J. Geophys. Res., 114, A10312, doi:10.1029/2008JA014029, 2009. 33286

Seppälä, A., Lu, H., Clilverd, M. A., and Rodger, C. J.: Geomagnetic activity signatures in wintertime stratosphere wind, temperature, and wave response, J. Geophys. Res., 118, 21692183, doi:10.1002/jgrd.50236, 2013. 33287, 33292, 33298

Shaw, T. and Perlwitz, J.: The life cycle of Northern Hemisphere Downward Wave Coupling 15 between the stratosphere and troposphere, J. Climate, 26, 1745-1763, doi:10.1175/JCLI-D12-00251.1, 2013. 33296

Shiotani, M. and Hirota, M.: Planetary wave-mean flow interaction in the stratosphere: a comparison between northern and southern hemispheres, Q. J. Roy. Meteor. Soc., 111, 309-334, 1985. 33294

Sinnhuber, B.-M., Kiesewetter, G., Burrows, J. P., Langematz, U., and Lubken, F. J.: Data assimilation and model calculations to study chemistry climate interactions in the stratosphere, Climate and Weather of the Sun-Earth System (CAWSES): Highlights from a Priority Program, 2012a. 33286

Sinnhuber, M., Nieder, H., and Wieters, N.: Energetic particle precipitation and the chemistry of the mesosphere/lower thermosphere, Surv. Geophys., 33, 1281-1334, doi:10.1007/s10712012-9201-3, 2012. 33285

Soukharev, B. E. and Hood, L. L.: The solar cycle variation of stratospheric ozone: Multiple regression analysis of long-term satellite data sets and comparisons with models, J. Geophys. Res., 111, D20314, doi:10.1029/2006JD007107, 2006. 33286, 33289

so van Loon, H. and Jenne, R. L.: The zonal harmonic standing waves in the Southern Hemisphere, J. Geophys. Res., 77, 992-1003, 1972. 33299

Waugh, D. W., Randel, W. J., Pawson, S., Newman, P. A., and Nash, E. R.: Persistence of the lower stratospheric polar vortices, J. Geophys. Res., 104, 191-202, 1999. 33300

\section{ACPD}

15, 33283-33329, 2015

Dynamical impact of energetic particles

K. Karami et al.

Title Page

Abstract

Introduction

Conclusions

References

Tables

Figures

$1<$

$>1$

4

Back

D

Close

Full Screen / Esc

Printer-friendly Version

Interactive Discussion 
Wilcox, L. J. and Perez, A. J. C.: Final warming of the southern hemisphere polar vortex in highand low-top CMIP5 models, J. Geophys. Res., 118, 2535-2546, 2013. 33300

Woods, T. and Rottman, G.: Solar Ultraviolet Variability over Time Periods of Aeronomic Interest, in: Atmospheres in the Solar System: Comparative Aeronomy, edited by: Mendillo, M., 5 Nagy, A., and Waite, J. H., AGU, Geophys. Monogr. Ser., Vol. 130, Washington, D.C., USA, 221-234, 2002. 33286

Yoden, S.: Bifurcation properties of a stratospheric vacillation model, J. Atmos. Sci., 44, 17231733, 1987. 33296

\section{ACPD}

\section{5, 33283-33329, 2015}

\section{Dynamical impact of} energetic particles

K. Karami et al.

\section{Title Page}

\section{Abstract}

Introduction

Conclusions

References

Tables

Figures

14 $>1$

4

Back

Close

Full Screen / Esc

Printer-friendly Version

Interactive Discussion 
Table 1. Summary of four EMAC simulations. All simulations (control, $\Delta \mathrm{O}_{3}-\mathrm{NH}, \Delta \mathrm{O}_{3}-\mathrm{SH}$ and $\Delta \mathrm{O}_{3}$-TS) are identical (except for prescribed ozone climatology according to Fig. 2).

\begin{tabular}{|c|c|c|c|c|c|}
\hline Resolution & Analysed time period & Running mode & Messy submodels & Radiation scheme & Climatological ozone \\
\hline $\begin{array}{l}\text { T42L90 } \\
\text { approximate box size }\left({ }^{\circ}\right) \\
2.8 \times 2.8\end{array}$ & $\begin{array}{l}100 \text { years under } \\
1982 \text { year condition }\end{array}$ & $\begin{array}{l}\text { Free-running } \\
\text { timeslice }\end{array}$ & $\begin{array}{l}\text { CLOUD } \\
\text { CONVECT } \\
\text { RAD4ALL } \\
\text { GWAVE }\end{array}$ & RAD4ALL-FUBRAD & FUB-ozone \\
\hline
\end{tabular}


Table 2. FUBRAD wavelength intervals in the shortwave radiation above $70 \mathrm{hPa}$.

\begin{tabular}{llll}
\hline Band & Gas & Wavelength $(\mathrm{nm})$ & Number of intervals \\
\hline Lyman-alpha & $\mathrm{O}_{2}$ & 121.6 & 1 \\
Schumann-Runge continum & $\mathrm{O}_{2}$ & $125.0-175.0$ & 3 \\
Schumann-Runge bands & $\mathrm{O}_{2}$ & $175.0-205.0$ & 1 \\
Herzberg cont./Hartley bands & $\mathrm{O}_{2} / \mathrm{O}_{3}$ & $206.2-243.9$ & 15 \\
Hartley bands & $\mathrm{O}_{3}$ & $243.9-277.8$ & 10 \\
Huggins bands & $\mathrm{O}_{3}$ & $277.8-362.5$ & 18 \\
Chappuis band & $\mathrm{O}_{3}$ & $407.5-682.5$ & 1 \\
\hline & & & Total: 49 \\
\hline
\end{tabular}

15, 33283-33329, 2015

Dynamical impact of energetic particles

K. Karami et al.

Title Page

Abstract

Conclusions

Tables

14

4

Back

Introduction

References

Figures

$>1$

$>$

Close

Full Screen / Esc

Printer-friendly Version

Interactive Discussion 


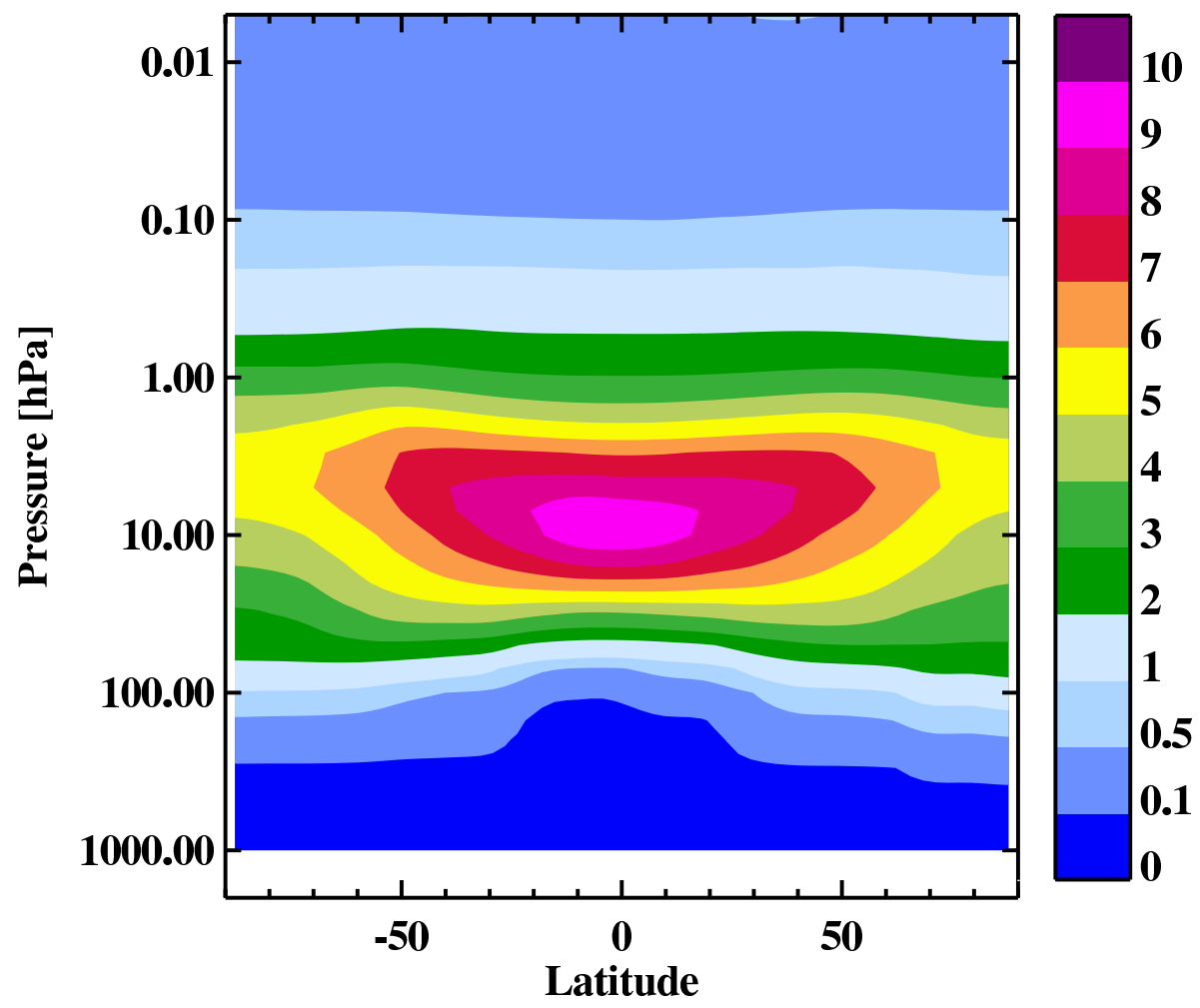

15, 33283-33329, 2015

Dynamical impact of energetic particles

K. Karami et al.

\section{Title Page}

Abstract

Conclusions

Tables

14

4

Back

Full Screen / Esc

Printer-friendly Version

Interactive Discussion

Figure 1. FUB annual climatology of ozone volume mixing ratio (ppmv). 

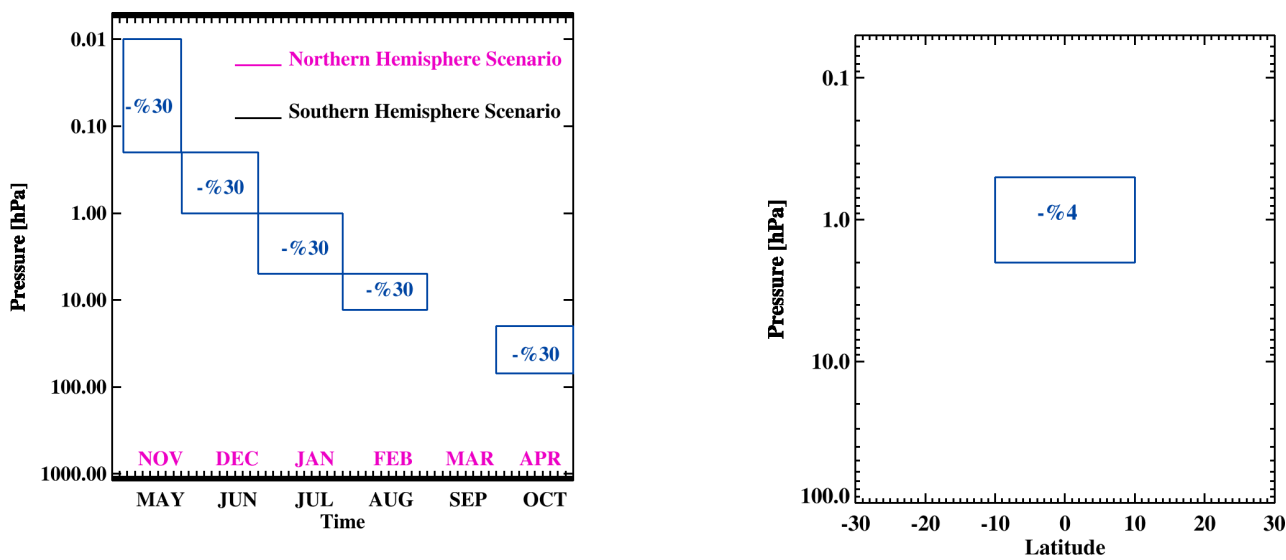

Figure 2. Left: Ozone depletion according to $\left(\Delta \mathrm{O}_{3}-\mathrm{NH}\right)$ and $\left(\Delta \mathrm{O}_{3}-\mathrm{SH}\right)$ scenarios. Right: Ozone depletion according to $\left(\Delta \mathrm{O}_{3}-\mathrm{TS}\right)$ scenario.
ACPD

15, 33283-33329, 2015

Dynamical impact of energetic particles

K. Karami et al.

Title Page

\section{Abstract}

Introduction

Conclusions

References

Tables

Figures

14 $>1$

4

Back

Close

Full Screen / Esc

Printer-friendly Version

Interactive Discussion 

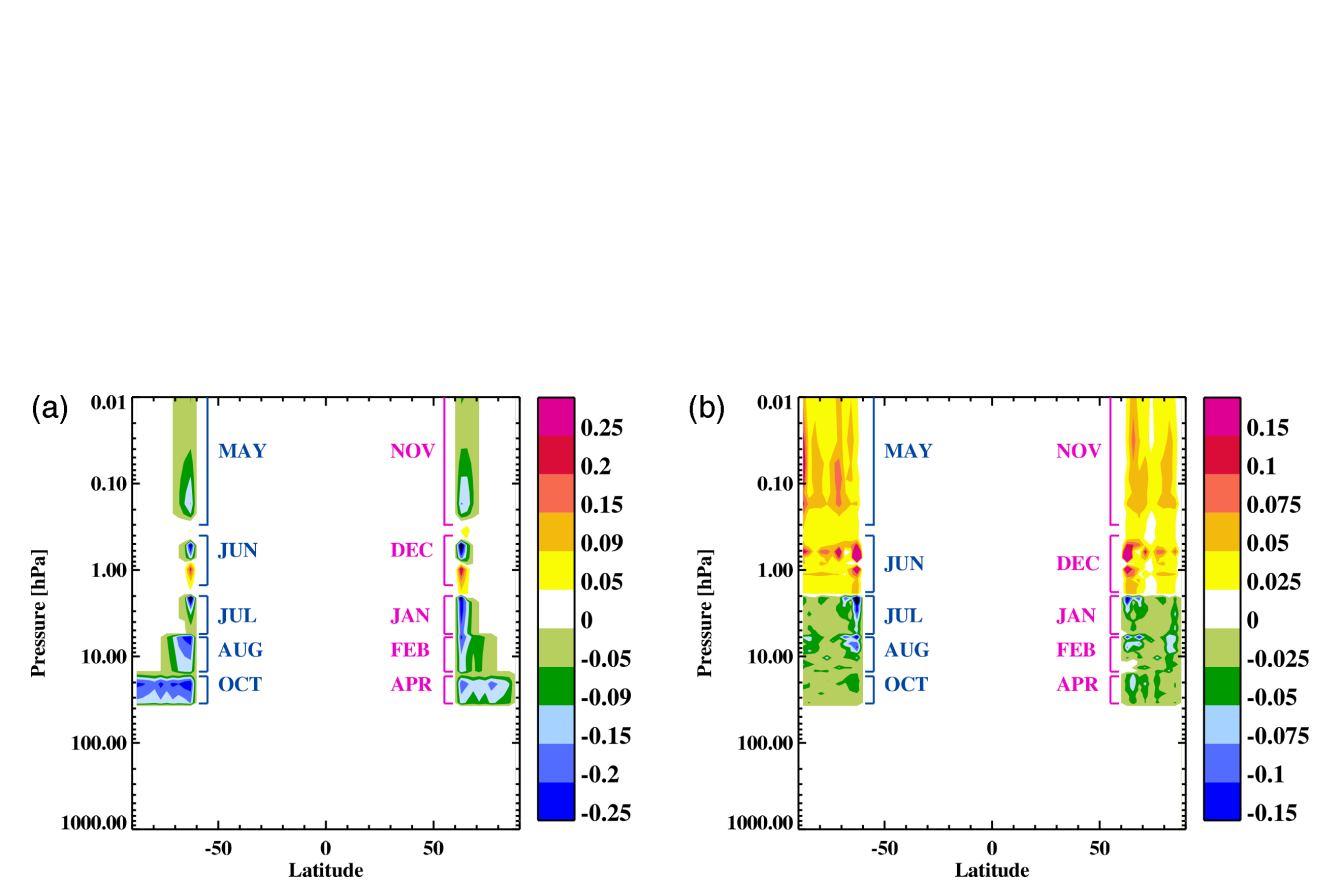

\section{ACPD}

15, 33283-33329, 2015

Dynamical impact of energetic particles

K. Karami et al.

Figure 3. Left: The initial change to the short wave heating rate due to imposed ozone depletion Scenarios. Right: The initial change to the long wave heating rate due to imposed ozone depletion scenarios. The units of both short wave and long wave radiation changes are $\mathrm{Kday}^{-1}$.

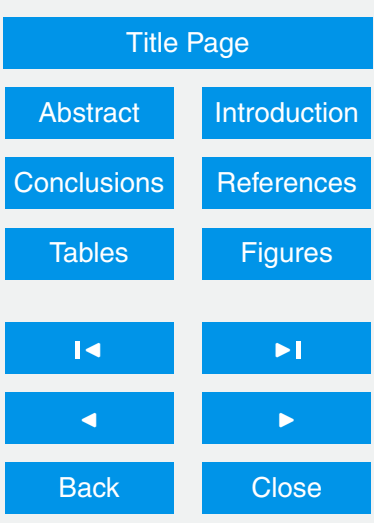

Full Screen / Esc

Printer-friendly Version

Interactive Discussion 

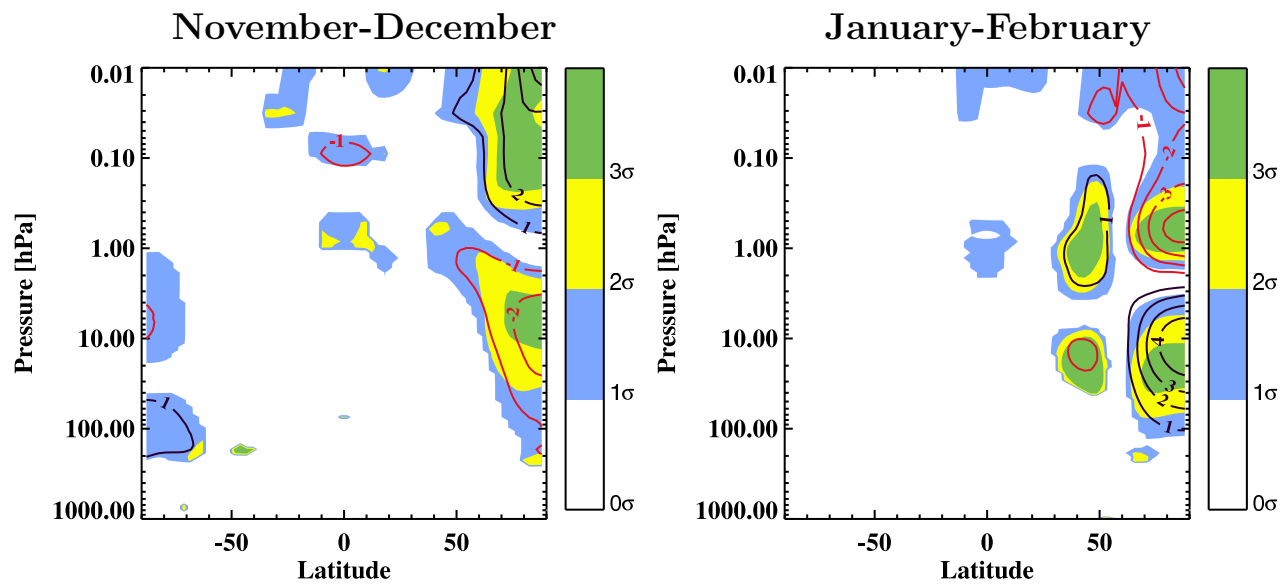

\section{ACPD}

\section{5, 33283-33329, 2015}

\section{Dynamical impact of} energetic particles

\section{K. Karami et al.}
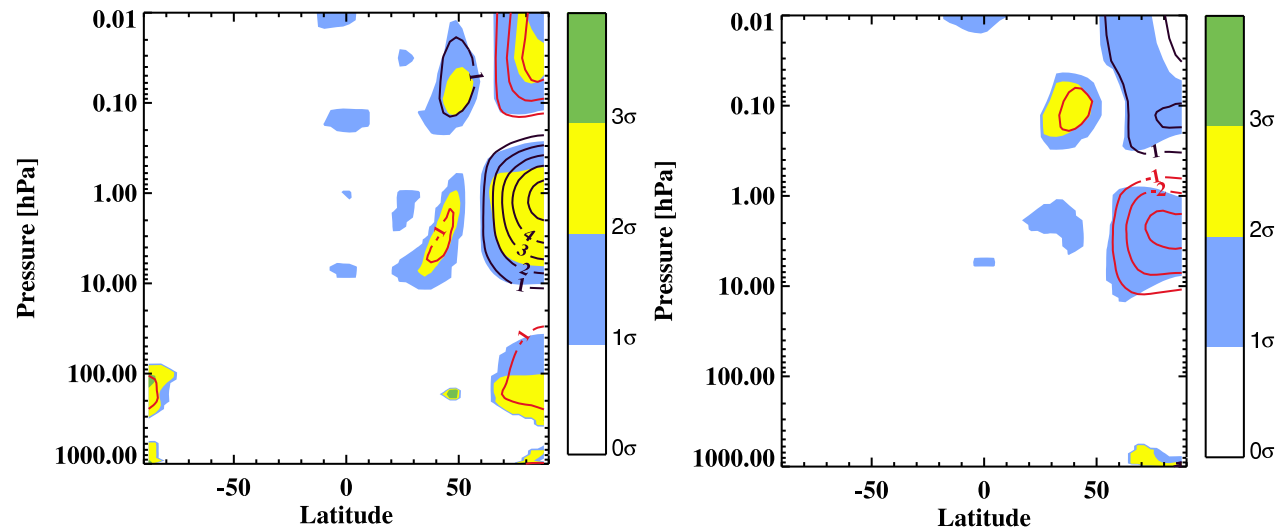

Figure 4. Monthly mean temperature changes between $\left(\Delta \mathrm{O}_{3}-\mathrm{NH}\right)$ scenario and control run for November, December, January and February. Contour values represent the monthly mean zonal mean temperature differences and shaded areas denote the significance level. The contour interval is $1 \mathrm{~K}$. Red contours show negative temperature anomaly while positive temperature anomalies are shown in black contours. 

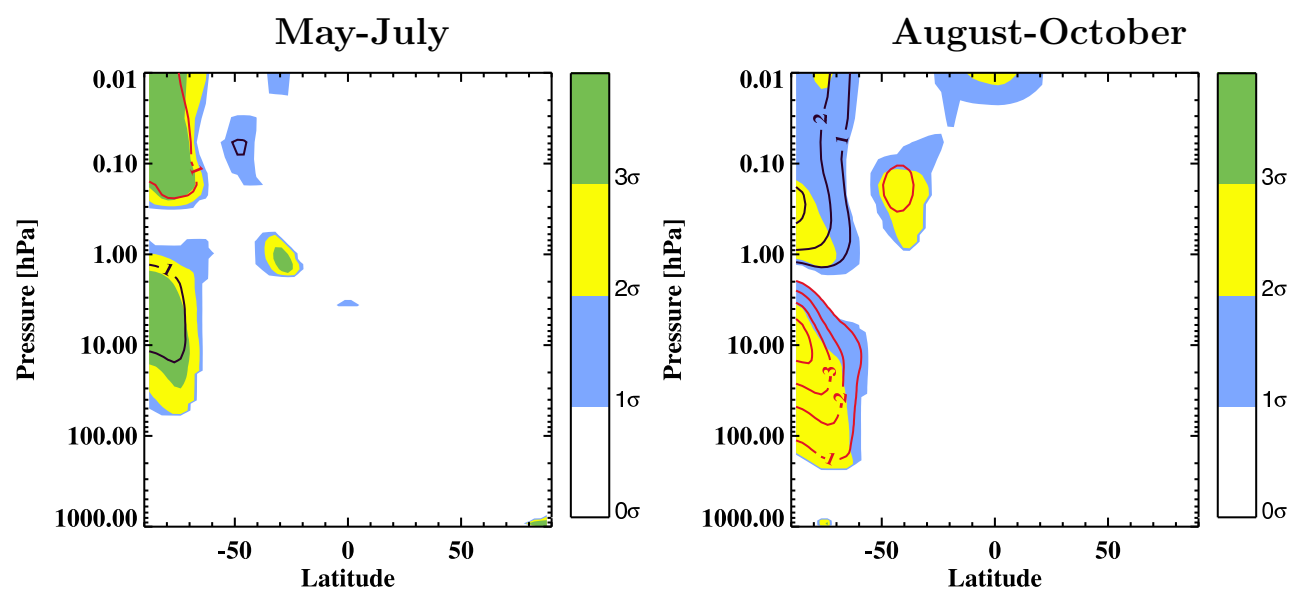

\section{ACPD}

\section{5, 33283-33329, 2015}

Dynamical impact of energetic particles

K. Karami et al.

Title Page

Abstract

Conclusions
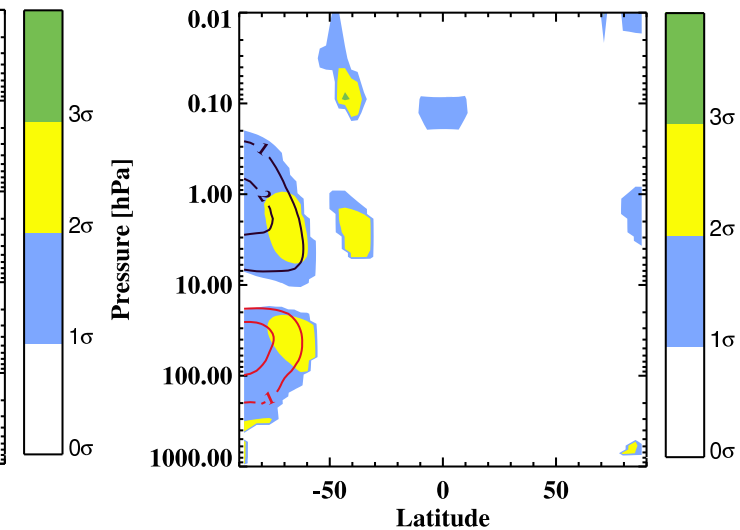

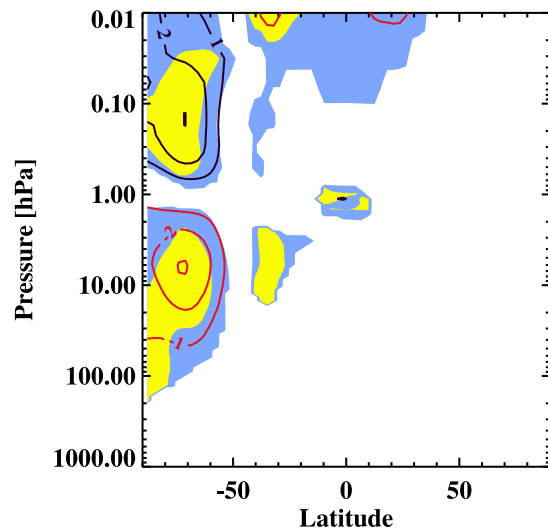

Figure 5. Monthly mean temperature changes in the model simulations for May, July, August and October for $\left(\mathrm{OO}_{3}-\mathrm{SH}\right)$ simulation.

Tables

14

4

Back

Introduction

References

Figures

DI

$>$

Close

\section{Full Screen / Esc}

Printer-friendly Version

Interactive Discussion 

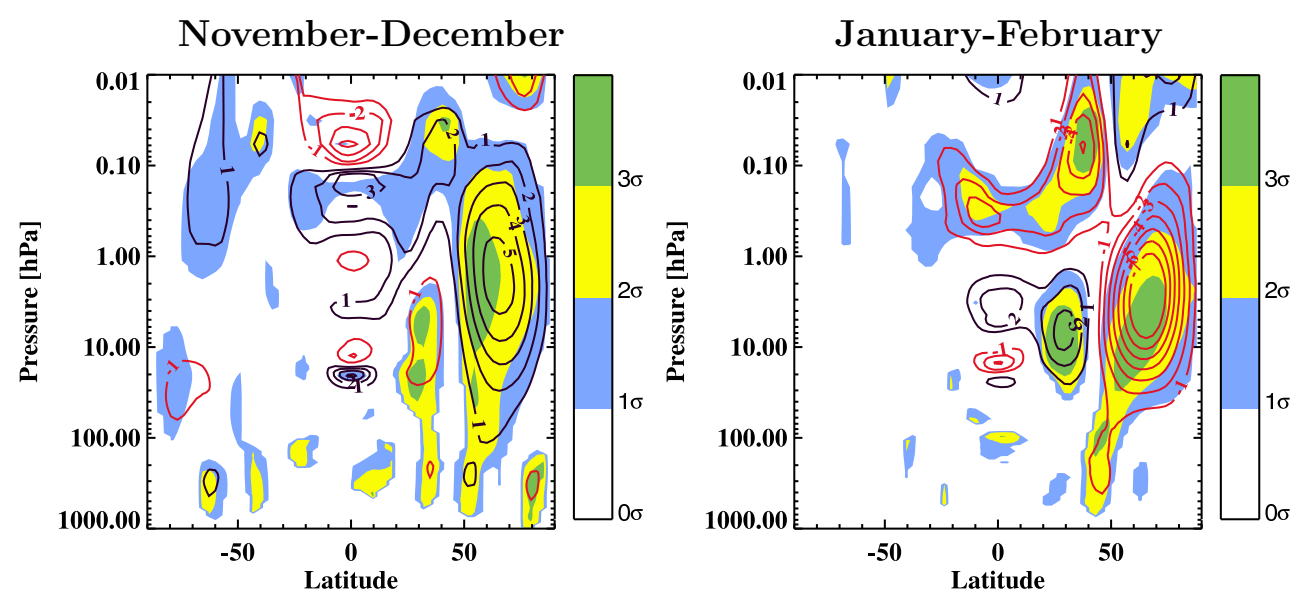

\section{ACPD}

\section{5, 33283-33329, 2015}

Dynamical impact of energetic particles

K. Karami et al.
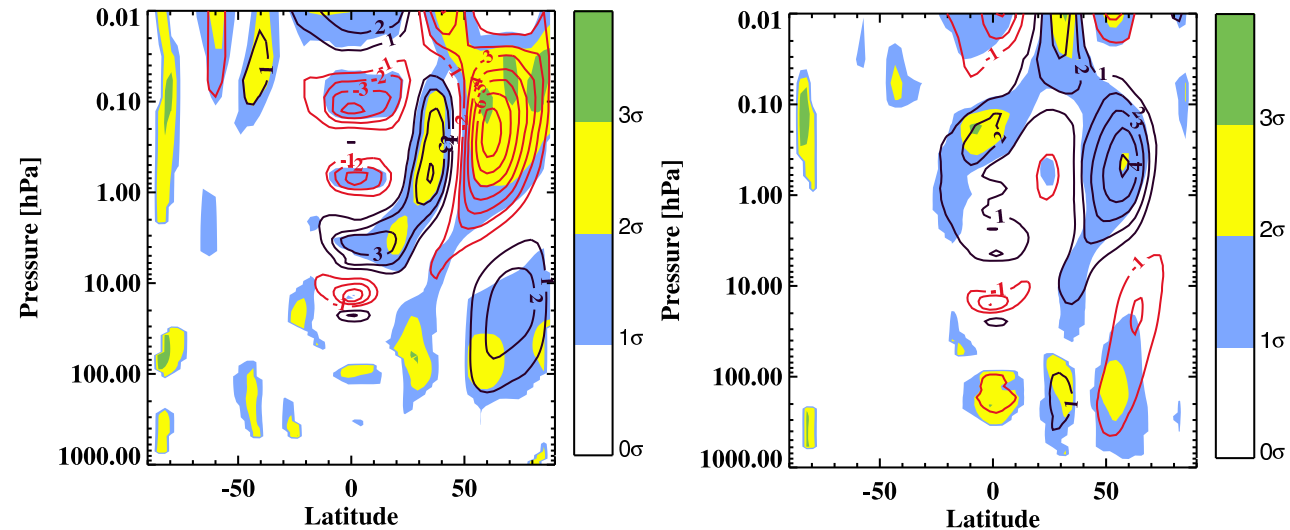

Figure 6. Monthly mean zonal mean zonal wind changes in the model simulations in November, December, January and February for $\left(\Delta \mathrm{O}_{3}-\mathrm{NH}\right)$ simulation. Contour values represent the monthly mean zonal mean zonal wind differences and shaded areas denote the significance level. The contour interval is $1 \mathrm{~ms}^{-1}$. Red contours show negative zonal wind anomaly while positive zonal wind anomalies are shown in black contours. 

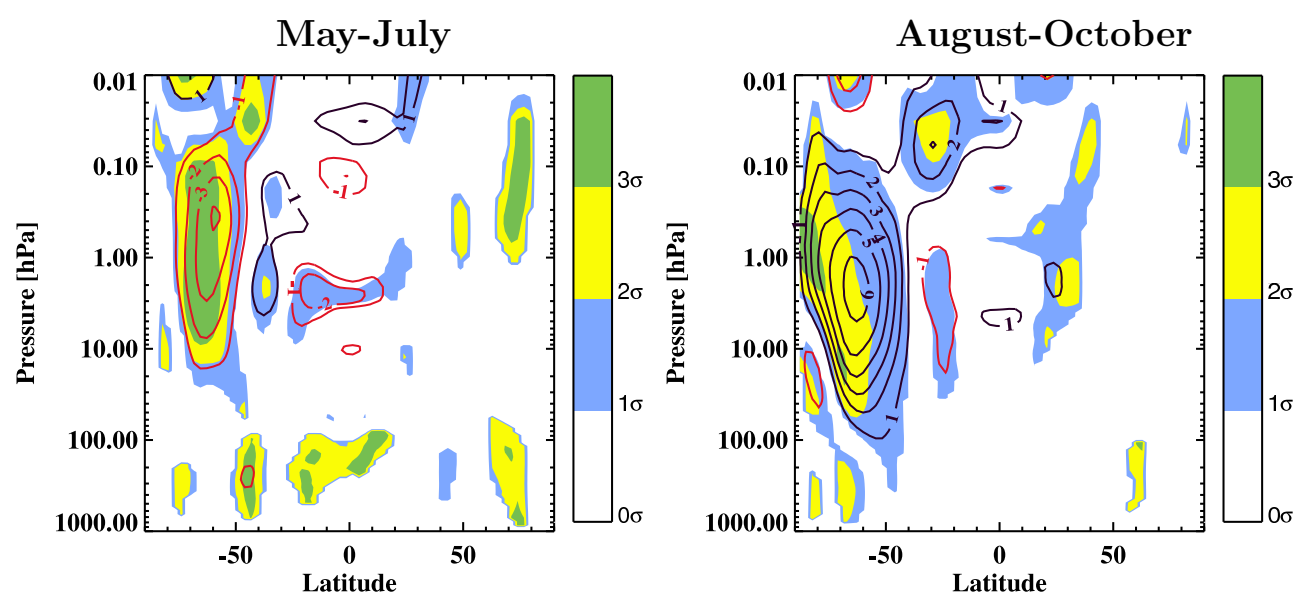

\section{ACPD}

15, 33283-33329, 2015

Dynamical impact of energetic particles

K. Karami et al.
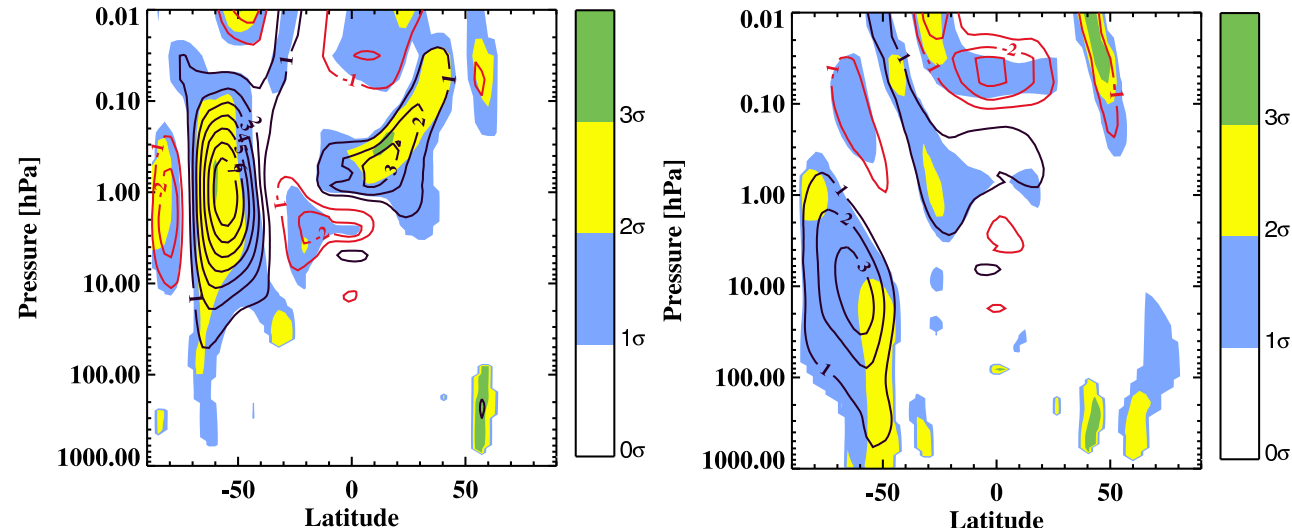

Figure 7. Monthly mean zonal wind changes in the model simulations for May, July, August and October for $\left(\Delta \mathrm{O}_{3}-\mathrm{SH}\right)$ simulation. 


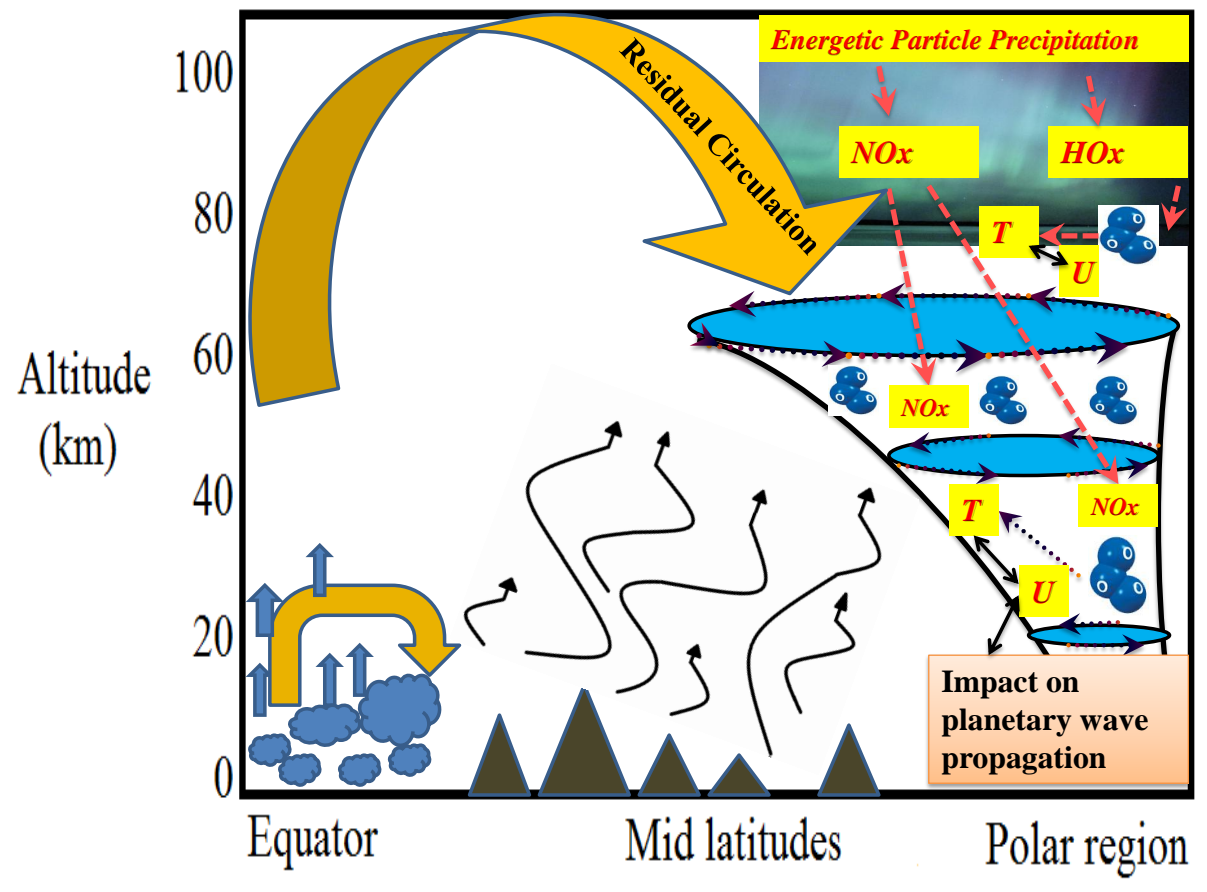

Figure 8. In the wintertime polar region, nitric oxide enriched air by energetic particle precipitation can be transported from the mesosphere and lower thermosphere down to the stratosphere due to downward branch of residual circulation, where it can destroy ozone. The depleted ozone has the potential to modify temperature, wind shear and planetary wave propagation and breaking.

\section{ACPD}

\section{5, 33283-33329, 2015}

\section{Dynamical impact of} energetic particles

K. Karami et al.

Title Page

\section{Abstract}

Introduction

Conclusions

References

Tables

Figures

14

$\rightarrow$

4

Back

Close

Printer-friendly Version

Interactive Discussion

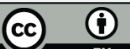




\section{November-December}
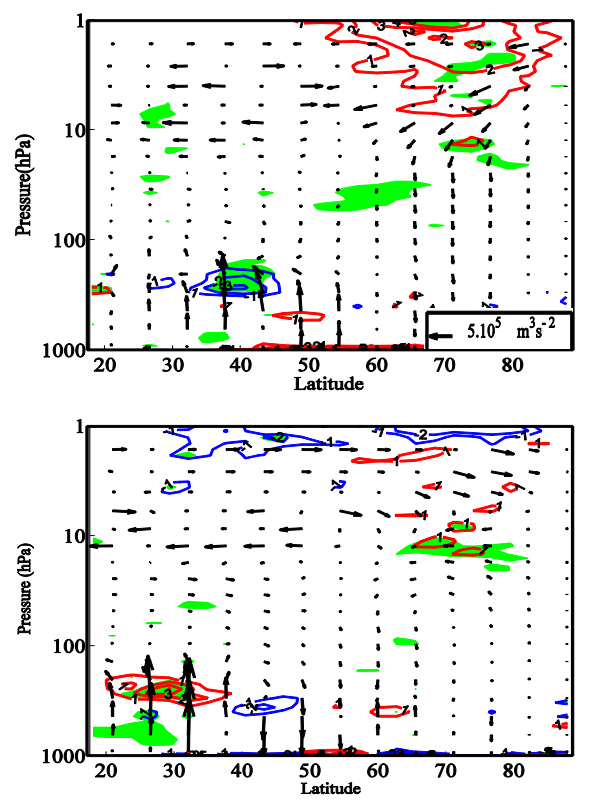

\section{January-February}
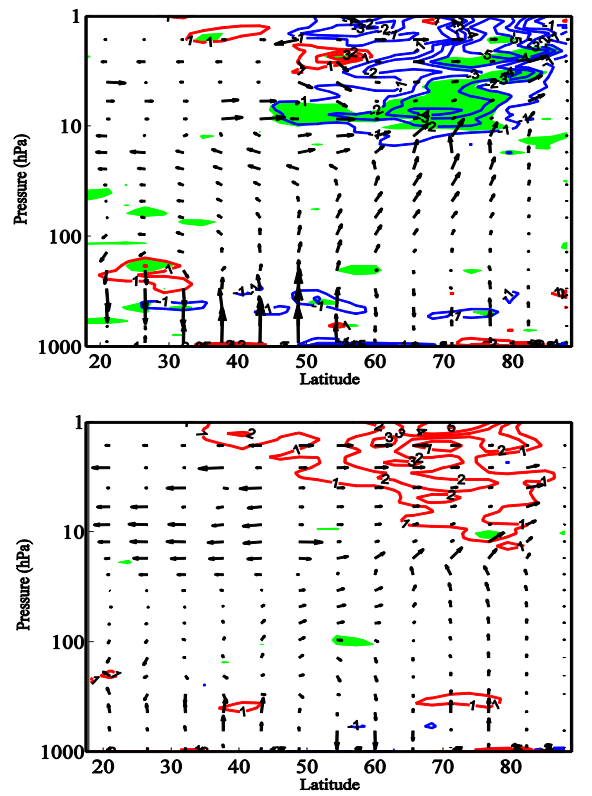

ACPD

15, 33283-33329, 2015

Dynamical impact of energetic particles

K. Karami et al.

Title Page

Abstract

Introduction

Conclusions

References

Tables

Figures

14

$>1$

4

Back

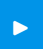

Close

\section{Full Screen / Esc}

Printer-friendly Version

Interactive Discussion EP flux divergences) denote acceleration of zonal flow by waves and blue lines (convergence of EP flux) denote deceleration of zonal flow. The contour interval is $1 \mathrm{~m} \mathrm{~s}^{-1}$ day $^{-1}$. 

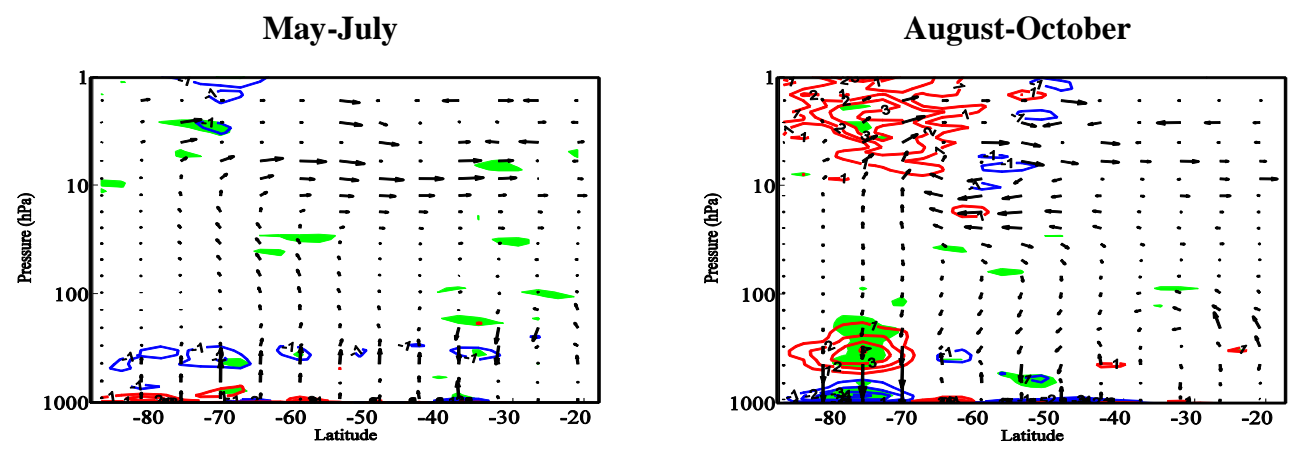

\section{ACPD}

15, 33283-33329, 2015

Dynamical impact of energetic particles

K. Karami et al.
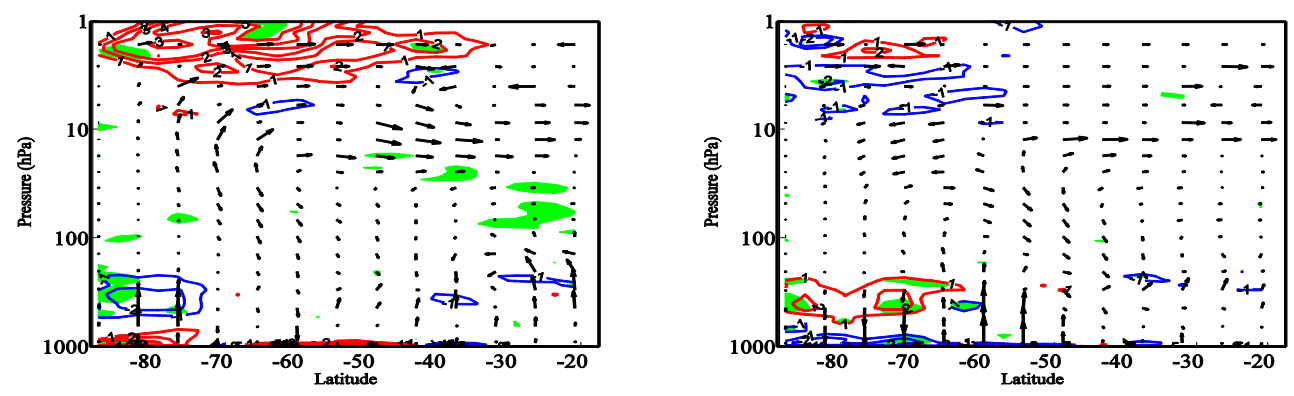

Title Page

Abstract

Introduction

Conclusions

References

Tables

Figures

14

I

4

Back

$>$

\section{Full Screen / Esc}

Printer-friendly Version

Interactive Discussion

(c) (i) 

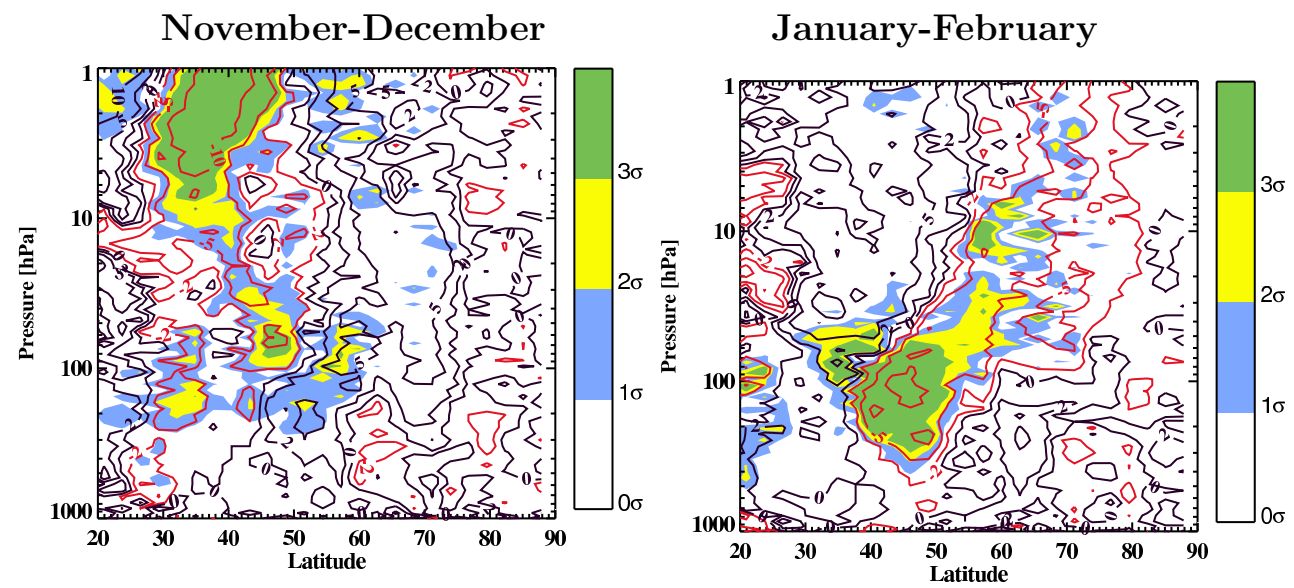

\section{ACPD}

\section{5, 33283-33329, 2015}

Dynamical impact of energetic particles

K. Karami et al.
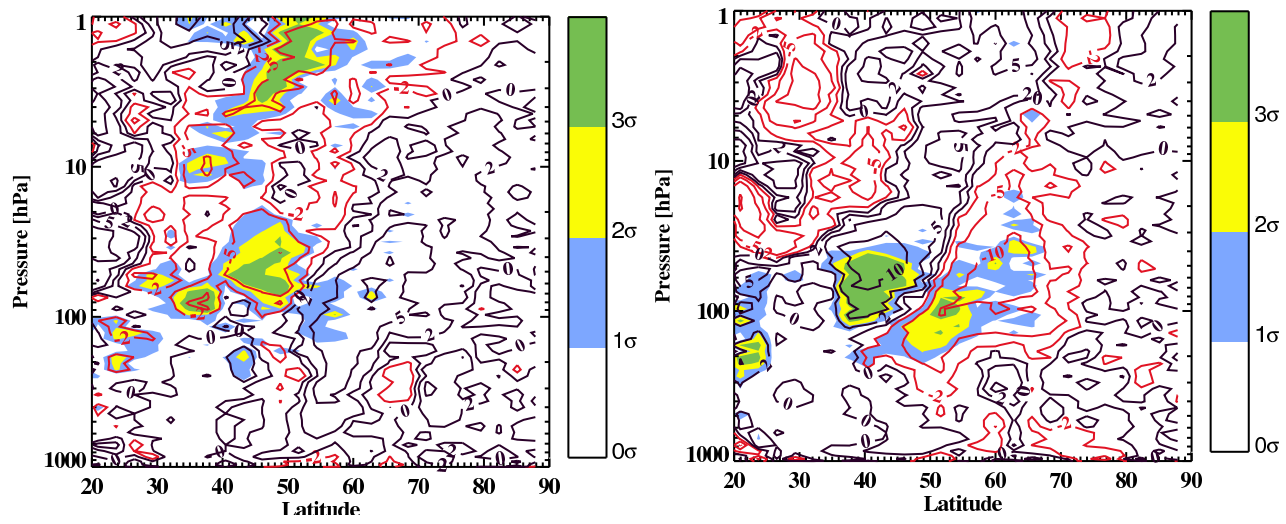

Conclusions

Title Page

Abstract

Introduction

References

Tables

Figures

14

$\rightarrow$

Back

>

Full Screen / Esc

Printer-friendly Version

Interactive Discussion

Figure 11. Changes in the propagation condition of Rossby waves for $Z W N=1$ for $\left(\Delta \mathrm{O}_{3}-\mathrm{NH}\right)$ simulation. Black contours show regions that are more conducive to Rossby wave propagation and red lines show regions that are less favourable for Rossby wave propagation. The contour interval is $[-20,-10,-5,-4,-3,-2,-1,0,1,2,3,4,5,10,20]$. 

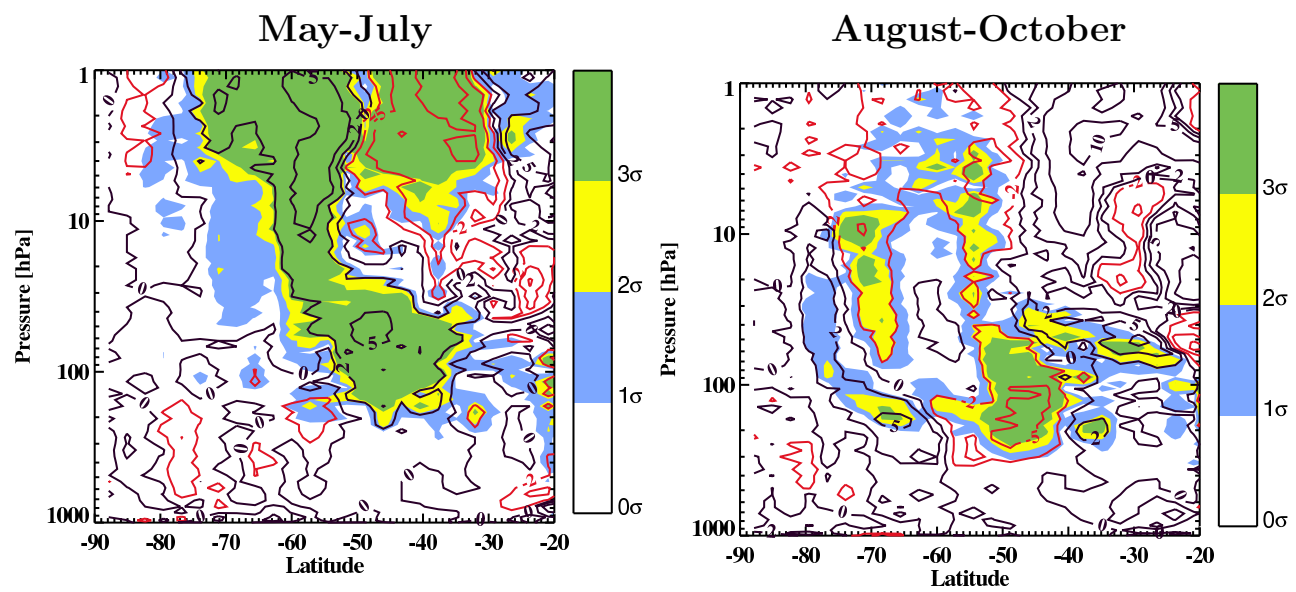

\section{ACPD}

15, 33283-33329, 2015

Dynamical impact of energetic particles

K. Karami et al.
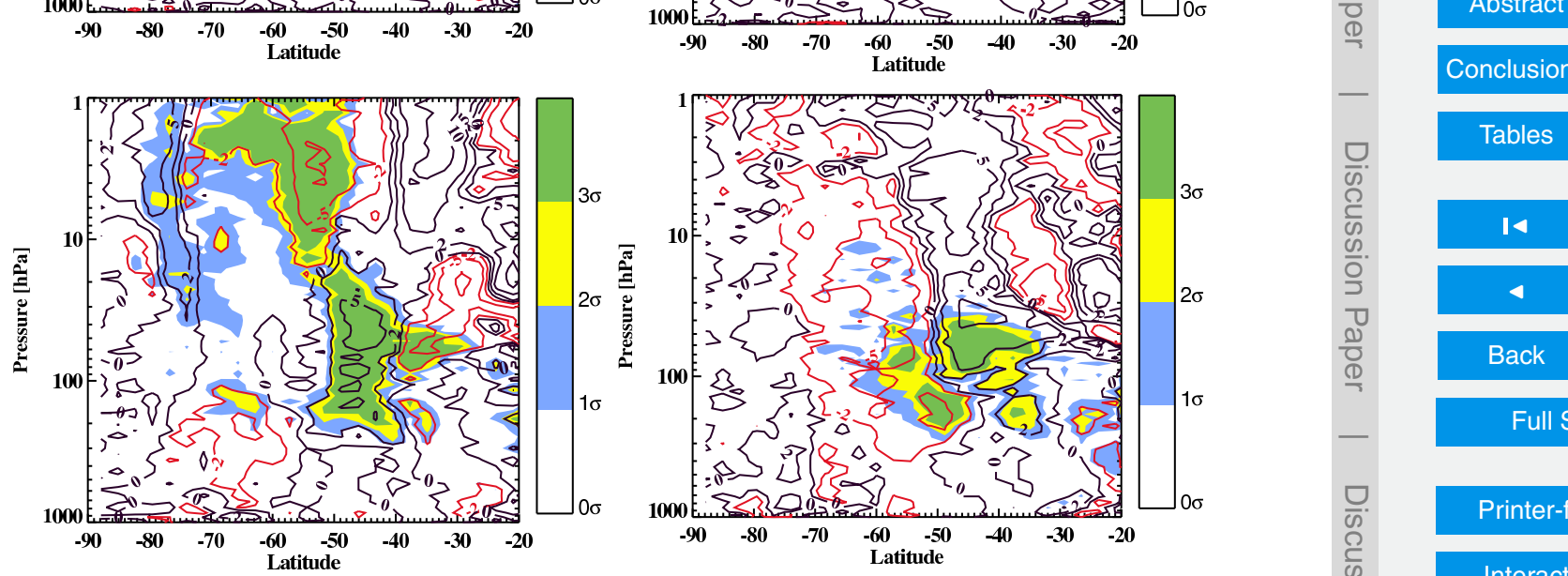

Conclusions

References

Tables

Figures

14

DI

Back

$>$

Full Screen / Esc

Printer-friendly Version

Interactive Discussion

Figure 12. Changes in the propagation condition of Rossby waves for $Z W N=1$ for $\left(\Delta \mathrm{O}_{3}-\mathrm{SH}\right)$ simulation. 


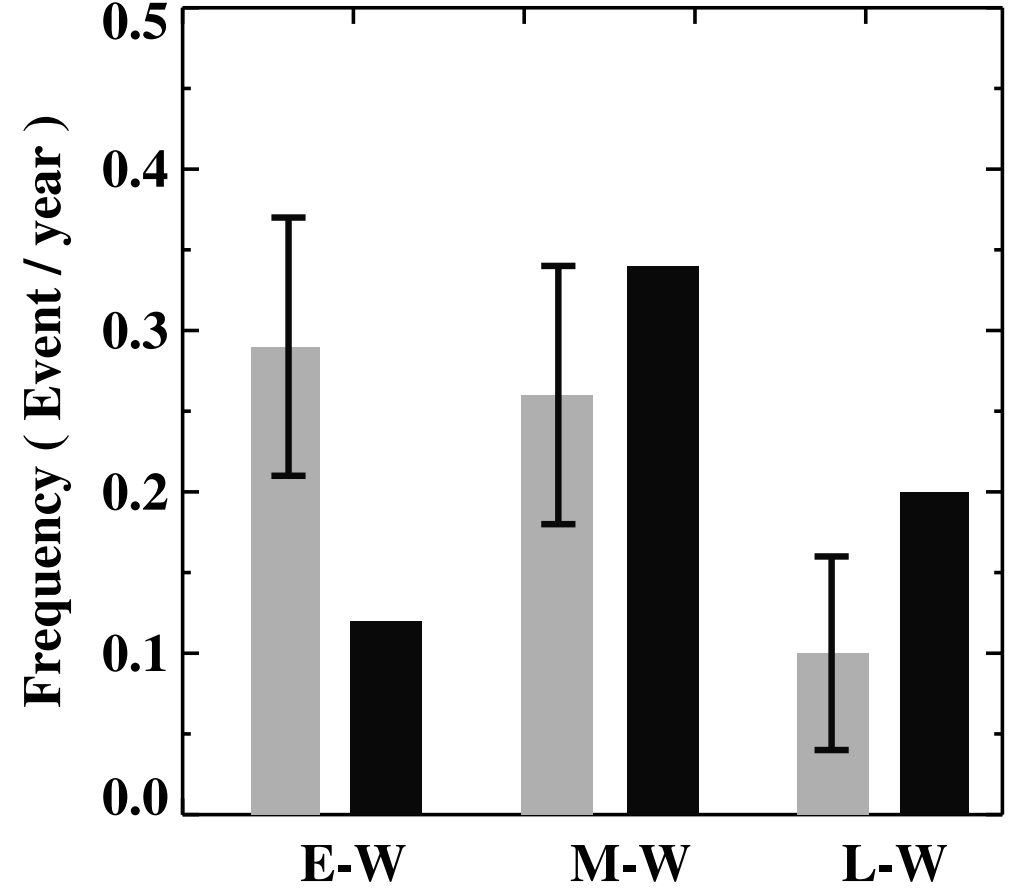

Figure 13. Frequency of sudden stratospheric warming in control simulation (gray) and $\left(\Delta \mathrm{O}_{3}\right.$ $\mathrm{NH}$ ) simulation (black). The error bars indicate the $2 \sigma$ level.

\section{ACPD}

15, 33283-33329, 2015

Dynamical impact of energetic particles

K. Karami et al.

\section{Title Page}

\section{Abstract}

Introduction

Conclusions

References

Tables

Figures

14 $>1$

4

Back

Close

\section{Full Screen / Esc}

Printer-friendly Version

Interactive Discussion 
$\left(\Delta O_{3}-T S\right)$ Scenario
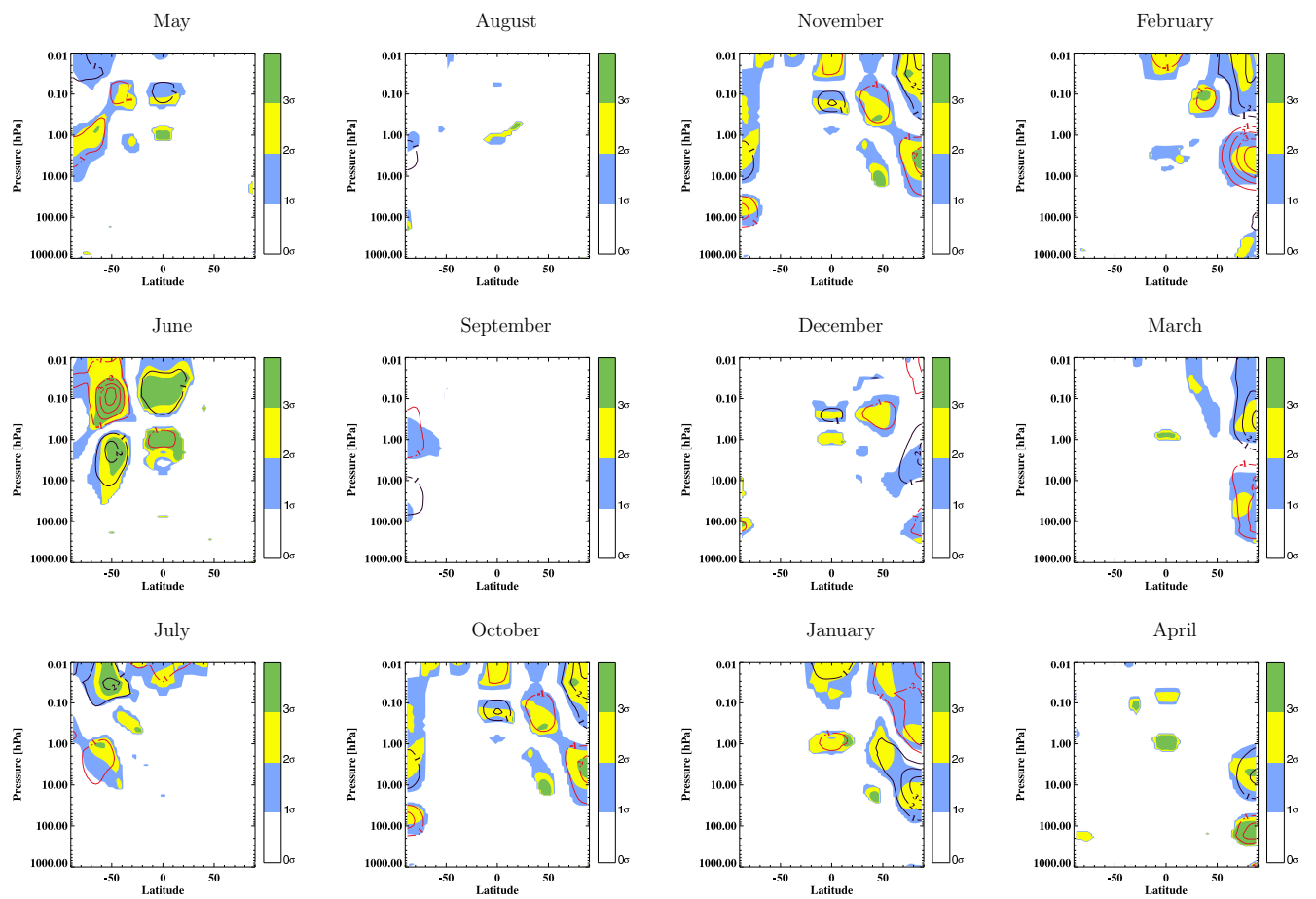

Figure 14. Monthly mean zonal mean temperature response of EMAC model to $\left(\Delta \mathrm{O}_{3}-\mathrm{TS}\right)$ scenario.
ACPD

15, 33283-33329, 2015

Dynamical impact of energetic particles

K. Karami et al.

Title Page

Abstract

Introduction

Conclusions

References

Tables

Figures

14

$>1$

4

Back

Close

Full Screen / Esc

Printer-friendly Version

Interactive Discussion

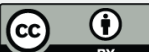


$\left(\Delta O_{3}-T S\right)$ Scenario
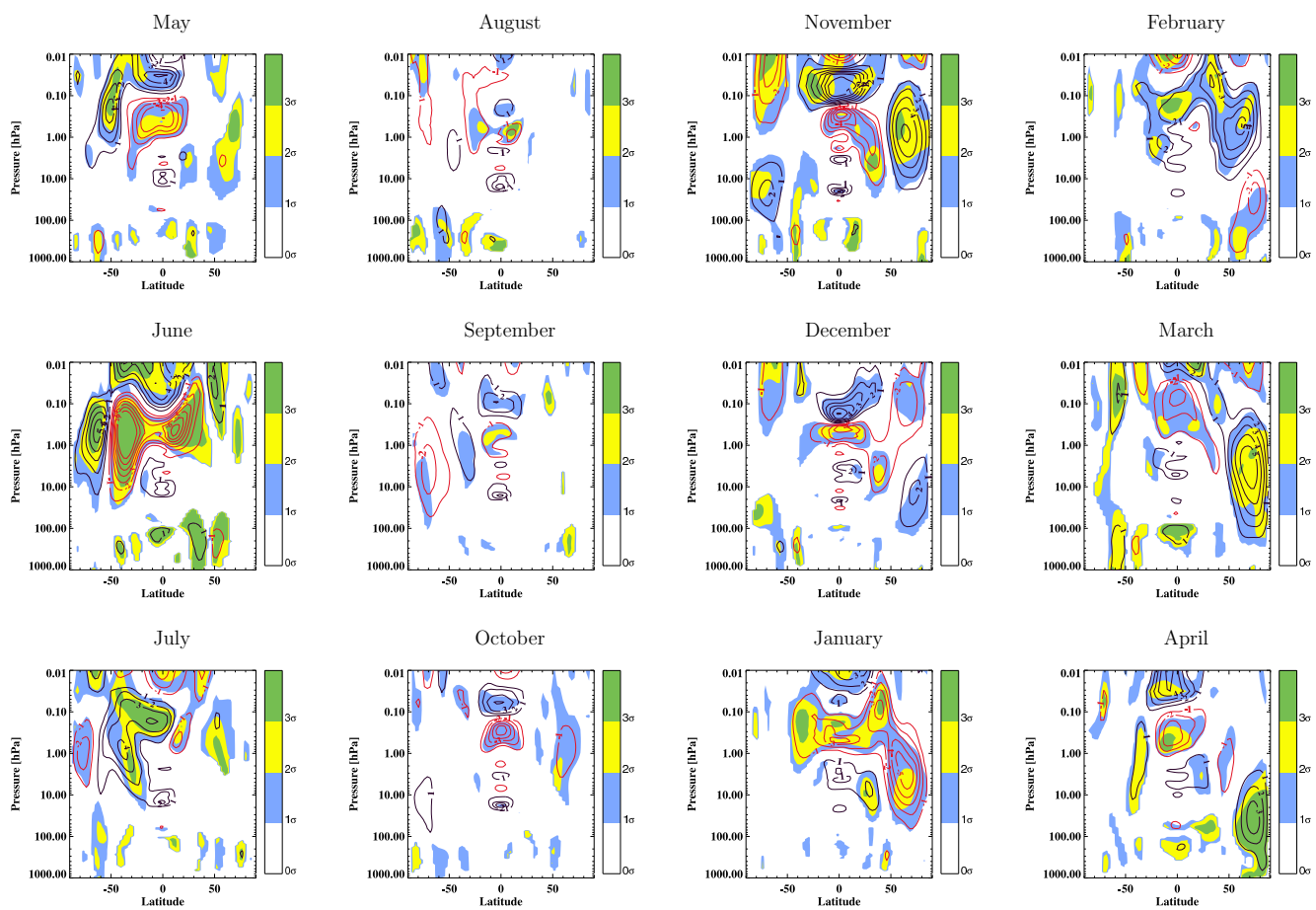

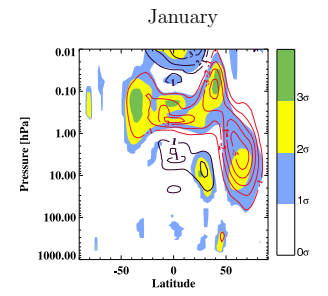

Figure 15. Monthly mean zonal mean zonal wind response of EMAC model to $\left(\Delta \mathrm{O}_{3}-\mathrm{TS}\right)$ scenario.

\section{ACPD}

15, 33283-33329, 2015

Dynamical impact of energetic particles

K. Karami et al.

\section{Title Page}

\section{Abstract}

Introduction

Conclusions

References

Tables

Figures

14

DI

4

Back

Close

Full Screen / Esc

Printer-friendly Version

Interactive Discussion

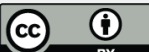

